OPEN ACCESS

Edited by:

Ramesh Akkina,

Colorado State University,

United States

Reviewed by:

Anand Kumar Kondapi,

University of Hyderabad, India

Marion E. G. Brunck,

Monterrey Institute of Technology and

Higher Education (ITESM), Mexico

*Correspondence:

Alexis M. Kalergis

akalergis@bio.puc.cl

Specialty section:

This article was submitted to Vaccines and Molecular Therapeutics,

a section of the journal

Frontiers in Immunology

Received: 01 July 2020 Accepted: 13 November 2020 Published: 11 December 2020

Citation:

Canedo-Marroquín G, Saavedra F,

Andrade CA, Berrios RV,

Rodríguez-Guilarte L, Opazo MC,

Riedel CA and Kalergis AM (2020)

SARS-CoV-2: Immune Response

Elicited by Infection and Development

of Vaccines and Treatments.

Front. Immunol. 11:569760.

doi: 10.3389/fimmu.2020.569760

\section{SARS-CoV-2: Immune Response Elicited by Infection and Development of Vaccines and Treatments}

\author{
Gisela Canedo-Marroquín ${ }^{1}$, Farides Saavedra ${ }^{1}$, Catalina A. Andrade ${ }^{1}$, \\ Roslye V. Berrios ${ }^{1}$, Linmar Rodríguez-Guilarte ${ }^{1}$, María C. Opazo ${ }^{2}$, Claudia A. Riedel ${ }^{2}$ \\ and Alexis M. Kalergis ${ }^{1,3 *}$

\begin{abstract}
${ }^{1}$ Millennium Institute of Immunology and Immunotherapy, Departamento de Genética Molecular y Microbiología, Facultad de Ciencias Biológicas, Pontificia Universidad Católica de Chile, Santiago, Chile, ${ }^{2}$ Millennium Institute on Immunology and Immunotherapy Departamento de Ciencias Biológicas, Facultad de Ciencias de la Vida, Universidad Andrés Bello, Santiago, Chile, ${ }^{3}$ Departamento de Endocrinología, Facultad de Medicina, Pontificia Universidad Católica de Chile, Santiago, Chile
\end{abstract}

The World Health Organization (WHO) announced in March a pandemic caused by Severe Acute Respiratory Syndrome Coronavirus 2 (SARS-CoV-2). This new infectious disease was named Coronavirus Disease 19 (COVID-19), and at October 2020, more than $39,000,000$ cases of SARS-CoV-2 have been detected worldwide leading to near $1,100,000$ deaths. Clinically, COVID-19 is characterized by clinical manifestations, such as fever, dry cough, headache, and in more severe cases, respiratory distress. Moreover, neurological-, cardiac-, and renal-related symptoms have also been described. Clinical evidence suggests that migration of immune cells to the affected organs can produce an exacerbated release of proinflammatory mediators that contribute to disease and render the immune response as a major player during the development of the COVID-19 disease. Due to the current sanitary situation, the development of vaccines is imperative. Up to the date, 42 prototypes are being tested in humans in different clinical stages, with 10 vaccine candidates undergoing evaluation in phase III clinical trials. In the same way, the search for an effective treatment to approach the most severe cases is also in constant advancement. Several potential therapies have been tested since COVID-19 was described, including antivirals, antiparasitic and immune modulators. Recently, clinical trials with hydroxychloroquine-a promising drug in the beginning-were suspended. In addition, the Food and Drug Administration (FDA) approved convalescent serum administration as a treatment for SARS-CoV-2 patients. Moreover, monoclonal antibody therapy is also under development to neutralize the virus and prevent infection. In this article, we describe the clinical manifestations and the immunological information available about COVID-19 disease. Furthermore, we discuss current therapies under study and the development of vaccines to prevent this disease.

Keywords: SARS-CoV-2, COVID-19, immune response, treatments, vaccines 


\section{INTRODUCTION}

Severe Acute Respiratory Syndrome Coronavirus 2 (SARS-CoV2), denominated by the International Committee on Taxonomy of Viruses (ICTV) (1), was first isolated during an outbreak in Wuhan, the Chinese province of Hubei in December 2019. This virus belongs to Coronaviridae family and betacoronavirus subfamily, known to infect mammals, such as bats, mice, and pangolins. An example of this subfamily is Severe Acute Respiratory Syndrome Coronavirus (SARS-CoV), which caused an epidemic in 2002 involving 26 countries with over 8,000 cases (1-4).

Since the outbreak in Wuhan in December 2019, SARS-CoV2 has demonstrated an accelerated contagious and spreading behavior (5). The fast transmission and the high number of cases affecting worldwide have made the management of virus spreading extremely difficult. The transmission of the virus is person-to-person through fomites and respiratory droplets $(5,6)$. Furthermore, fecal shedding has been shown up to 5 weeks after the clinical recovery (7-9). Therefore, it is hypothesized that fecal-oral transmission could be another propagation route for SARS-CoV-2 (10), with an incubation period that can last approximately up to 7 days after exposure to the virus $(6,11$, 12). Interestingly, asymptomatic individuals display viral loads that have shown to be challenging to detect during the period of incubation $(13,14)$. Consequently, the spreading of the virus has no contention, and therefore researchers actively work to find vaccines and treatments for this pathogen.

In this article we discuss the current knowledge about the innate and adaptive immune response during coronavirus disease (COVID-19). Furthermore, we describe the scientific strategies currently undergoing testing for prophylaxis or treatment for COVID-19.

\section{SARS-COV-2 VIRION CHARACTERISTICS AND TARGET RECEPTOR IN CELLS}

SARS-CoV-2 is a positive-stranded RNA virus with an estimated genome size equal to $29.9 \mathrm{~kb}$ (15). In contrast, the genome size of previous pathogenic coronaviruses, such as SARS-CoV and the Middle East Respiratory Syndrome virus (MERS) is $27.9 \mathrm{~kb}$, and $30.1 \mathrm{~kb}$, respectively $(3,16)$. It has been predicted that SARS$\mathrm{CoV}-2$ has fourteen open reading frames (ORFs) that encode for four structural proteins: spike (S) that promotes the viral entry to host cell, membrane protein $(\mathrm{M})$ that induces the membrane curvature and allows the union with nucleocapsid $(\mathrm{N})$ protein. Additionally, the $\mathrm{M}$ protein interacts with the envelope protein (E) and allows virus assembly and release $(15,17,18)$. Fifteen

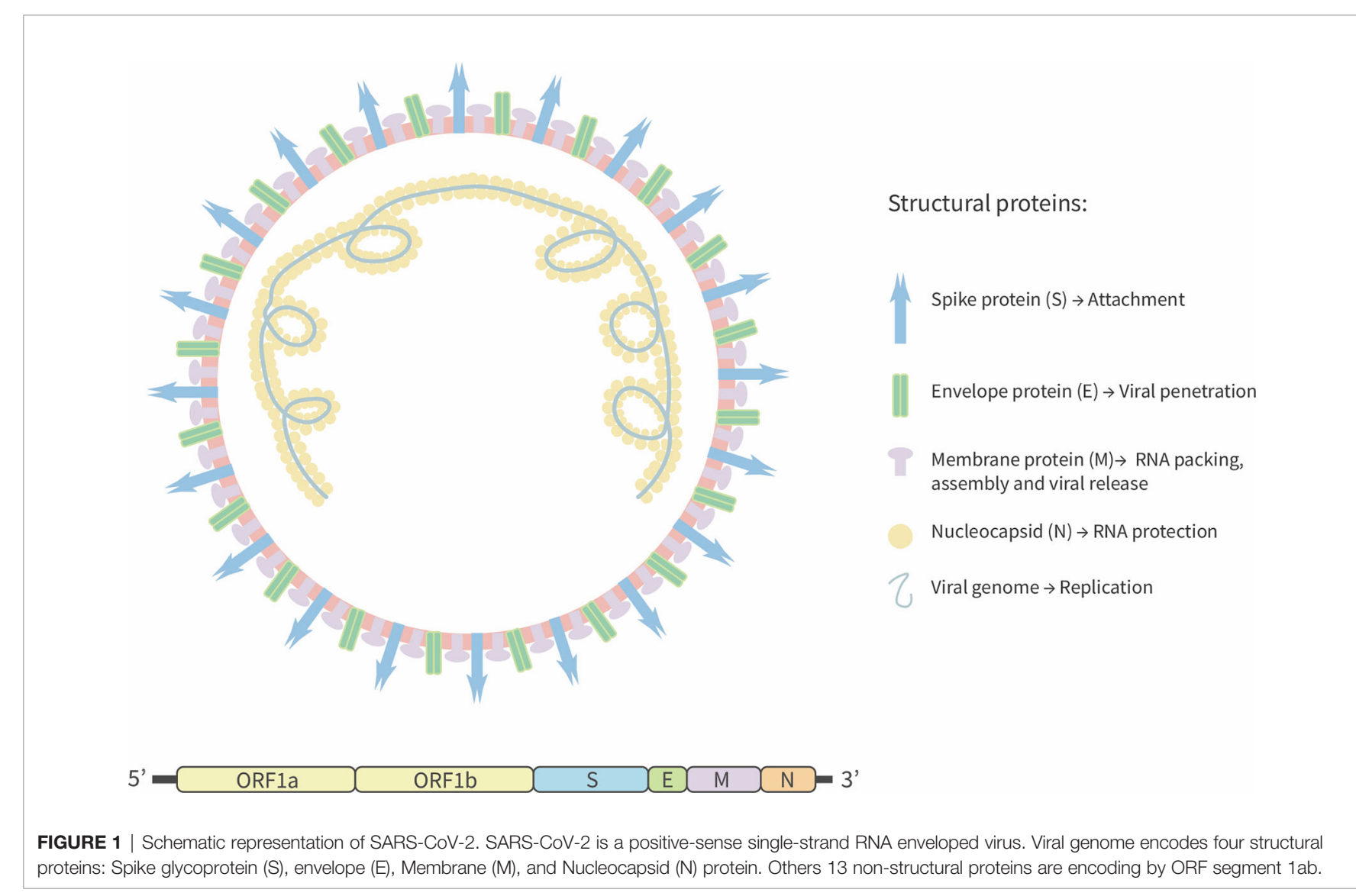


non-structural proteins are also encoded by the ORFab portion (15) (Figure 1). Similar to SARS-CoV, SARS-CoV-2 Sglycoprotein is cleaved by a transmembrane serine-protease 2 (TMPRSS2), producing two surface proteins S1 and S2 (19). The virus attaches to the host cell by the S1-domain by means of the receptor-binding domain (RBD), which binds to the Angiotensin Converted Enzyme 2 (ACE2) receptor to promote the viral fusion and the release of the viral genome into the host cells that is required for the production of new virions (20).

The ACE2 receptor can be expressed by cells from the respiratory system, arteries, heart, and digestive tract (20-22). In the respiratory tract, the receptor is expressed by pneumocytes type I and II located in the throat and lungs, as well as by alveolar macrophages (20). Despite the low presence of ACE2 both in the upper and lower respiratory tracts, the tropism for type II alveolar cells can be explained by the presence of proteases that contribute to the viral proteolytic processing required for SARS-CoV-2 entry (23). Three proteases have been described that can prime the S-protein: TMPRSS2, furin, and cathepsin B/L $(22,24,25)$. TMPRSS2, as described above, cleaves the $S$ protein in the S2 subunit at the RRAR motif, particularly in a highly basic domain (20). The furin protease also contains the cleavage RRAR sequence $(23,26)$. It has been described that furin can be secreted by the alveolar epithelium cells and work on neighboring cells (26). The synergy between furin and TMPRSS2 allows the viral entry to the cells $(20,27)$. According a predicted analysis cathepsin $\mathrm{B} / \mathrm{L}$ are endosomal cysteine proteases that facilitate the entry of SARS-CoV into the cells; however, the contribution of these enzymes to SARS-CoV-2 entry has not been described (28).

\section{CLINICAL FEATURES OF SARS-COV-2}

COVID-19 displays clinical manifestations any time from 6 to 14 days after the exposure to SARS-CoV-2 (29). The most frequent symptoms are fever, nasal congestion, myalgia, headache, and cough $(5,30)$. However, anosmia and encephalitis have also been described for COVID-19 patients (31). Further, respiratory impairment occurs with severe clinical manifestations, such as respiratory distress and pneumonia (32). Comorbidities, including hypertension, diabetes, cardiovascular, and respiratory diseases, are closely associated with the severity of disease, mainly because patients with these ailments could develop pneumonia and require intensive care unit hospitalization, mechanical ventilation, and eventually extracorporeal membrane oxygenation (33). Symptoms could lead to multiple organ inflammation, resulting in organ failure $(34,35)$ that can cause death to the affected patient $(30,36)$ (Figure 2). Globally, the lethality is near to $2 \%-3 \%(37,38)$, with the elderly population as the most susceptible (39). Interestingly, it has been reported that after the illness, a minor percentage of patients can show the reactivation of SARS-CoV-2 (40). Even more, virus reactivation can lead to the relapse of the patient $(41,42)$. So far, the hospitalization of the patients that relapse has not been described (43).
In addition to the involvement of lungs, heart, kidney, liver, and bowels, SARS-CoV-2 seems to reach the central nervous system (CNS), causing a broad range of clinical manifestations that will be discussed next (44). Similarly to other respiratory viruses (45-49), the ability of coronavirus to enter the CNS has been demonstrated by using murine animal models (50) and in vitro neuronal cell cultures $(51,52)$. Neurological symptoms were also shown for other coronaviruses, such as SARS-CoV and HCoV-OC43 (53-55). It has been suggested that neurons are a potential SARS-CoV-2 target, because these cells express the ACE2 receptor (31). Other cells from the CNS like astrocytes and oligodendrocytes are also targets of SARS-CoV-2 infection due to they also express the ACE2 receptor (56). In addition, a recent report showed that SARS-CoV-2 could be detected in neurons and microglia from deer mice at day 6 post-infection (44). Consistent with this notion, is the observation that $36.4 \%$ of patients can display several neurologic symptoms, including headache, encephalitis, impaired consciousness, and even the Guillain-Barre syndrome (57-59). Possible routes for the virus to enter into the CNS are the peripheral nerves and the bloodbrain barrier (BBB), whether the virus uses immune cells or to go through the $\mathrm{BBB}$ remains to be defined $(45,60)$. Along these lines, it has been observed that patients infected by SARS-CoV-2 suffer from olfactory and taste disorders (OTDs) (57). Symptoms that seems to be more frequent in women than in men (61). Among the symptoms of taste disorders, dysgeusia and ageusia were observed, while hyposmia, and anosmia also occurred as olfactory disorders (62). It has been demonstrated that SARS$\mathrm{CoV}$ can enter the CNS through the olfactory bulb (62). Since SARS-CoV-2 generates symptoms involving OTDs, it can be suggested that this virus can arrive at the olfactory bulb and enter the CNS (63). However, because the olfactory sensory neurons were found not to express the ACE2, SARS-CoV-2 could not infect them, unless it uses another receptor that has not been described yet (63).

Another coronavirus as $\mathrm{HCoV}-\mathrm{OC} 43$, is thought to enter the CNS via the hematogenous route as an immune cell carry-on (64). It was suggested that SARS-CoV-2 also can enter the CNS through a hematogenous route. Using in vitro models for the $\mathrm{BBB}$, the presence of ACE2 receptors was shown in blood vessels from the frontal cortex along with the brain microvascular endothelium (BMVEC) (65). Furthermore, the $S$ protein seems capable of disrupting the BBB (65). Additionally, there is evidence for the presence of the virus in the cerebrospinal fluid (CSF), proving that SARS-CoV-2 can reach the CNS (62). An alternative to the hematogenous route for SARS-CoV-2 may be transporter or pass through the tight junctions from the epithelial cells in the choroid plexus and the endothelial cells from the veins located in the subarachnoid space, which are the cells that are part of the blood-CSF barrier (BCSFB) $(65,66)$.

Interestingly, the ability of SARS-CoV-2 to invade the CNS is thought to be associated with respiratory failure in patients with COVID-19, though this notion still remains to be conclusively defined $(67,68)$. Further studies are needed to evaluate the effect that the virus has on the CNS and the neurological symptoms that this pathogen causes in humans. 
A

Most Frequent Symptoms

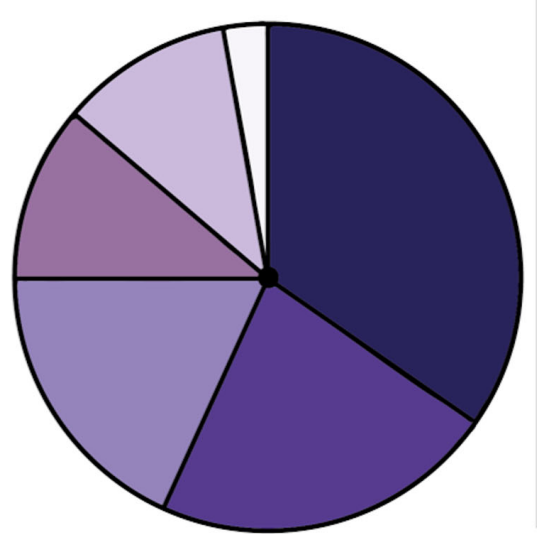

B

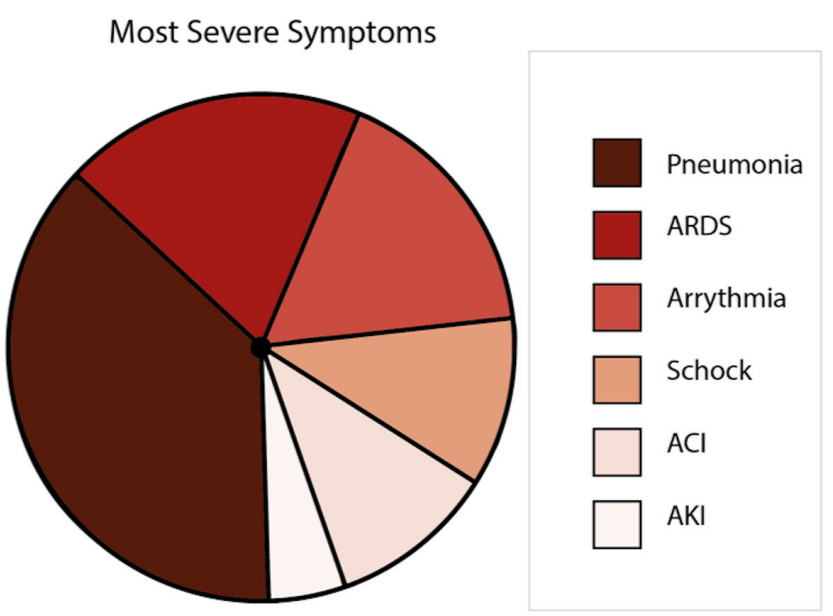

FIGURE 2 | Symptoms caused by COVID-19 disease. (A) Is a representation of the most frequent symptoms in patients with SARS-CoV-2, where the most frequent symptom is the fever, followed by fatigue, dry cough, myalgia, dyspnea, and headache. (B) Is a representation of the most severe symptoms in patients with SARS-CoV-2, where pneumonia is the most common, followed by acute respiratory distress syndrome (ARDS), arrhythmia, shock, acute cardiac injury (ACl), and acute kidney injury (AKI).

\section{THE IMMUNE RESPONSE TO SARS-COV-2}

Although the immunopathology of coronaviruses remains poorly understood, the elucidation of the molecular and cellular mechanisms behind the immune response triggered by SARS-CoV-2 will help to develop vaccines and therapeutic strategies to control the infection or to improve the clinical progression of patients. Because SARS-CoV-2 is a novel virus, the immune response elicited by this pathogen is not yet comprehended. In this section, we discuss the main findings relative to the immune response to the virus and how this response affects the lungs.

\section{The Innate Immune Response Induced by SARS-CoV-2}

Much remains to be understood about the molecular immune mechanism involved in SARS-COV-2 infection. Commonly, pathogen-associated molecular patterns (PAMPs) from microorganisms are recognized by pattern-recognition receptors (PRRs) (69). When viral fusion occurs, the viral genome can be recognized by various PRRs expressed by host cells (70-72). Among the PRRs that recognize viral RNA, it is essential to highlight toll-like receptors (TLR) 7 and 8 that trigger the myeloid differentiation primary response (MyD88) pathway upon binding to viral ssRNA $(73,74)$. Additionally, viral proteins can be recognized by TLRs and trigger the TLR4-MyD88 pathway (75). All these pathways promote the expression of type I IFNs $(73,76)$. Nevertheless, a deficient type I IFN response is observed during SARS-CoV-2 infection in vitro (77). An inefficient type I and type III IFN response has been suggested to associated with increased patient fatality. No IFN- $\beta$ and IFN- $\lambda$ could be detected in plasma samples and lung biopsies from
SARS-CoV-2 individuals (78, 79). Type I interferon levels increased in patients suffering from severe disease and that improved after a critical condition (78). Even though the TLR4 pathway involves the activation of the Tank-binding kinase 1 (TBK1), studies have shown that this kinase does not get activated during an in vitro infection with SARS-CoV-2 (77). All these in vitro results suggest that SARS-CoV-2 could inhibit the IFN pathway at one or more of the steps mentioned above. Contrary to the in vitro results, during infection of mice with SARS-CoV-2, an increase in IFN- $\alpha$ and TBK-1 was observed, with a peak at day 6 post-challenge, followed by a decrease in the expression of these molecules (44). These data suggest that there might be an IFN response during the infection in vivo, which declines later as the viral loads from the lung tissue (44).

Hematological studies have shown a progressive increase in the number of neutrophils in the peripheral blood of COVID-19 patients $(40,80-82)$, especially in those cases with respiratory distress (83). Furthermore, pulmonary infiltration has been found in autopsies of COVID-19 patients (84). On the other hand, COVID-19 patients had shown low eosinophil levels that could be considered as a laboratory biomarker (40, 80, 81, 85). Moreover, the presence of natural killer (NK) cells is reduced in COVID-19 patients, which might be associated with higher levels of chemokines ligand (CXCL) 9 and 16 (77). It is thought that a decrease in IFN- $\gamma$ secretion could be associated with an impairment of the antiviral immune response (81, 86-89).

Some patients have shown a cytokine storm release (CRS) response associated with a negative prognosis, including death (90). CRS is an excessive inflammatory response induced by the SARS-CoV-2 infection, which in severe cases consists of the reduction of $\mathrm{T}$ cells and diffusing airway damage due to the infiltration of immune cells and the hyaline membrane formation $(91,92)$. COVID-19 severe cases show increased 
levels of several cytokines and chemokines, at least five-fold or more than healthy controls (93). Among them IL-2, IL-7, granulocyte-colony stimulating factor (G-SCF), interferon gamma-induced protein 10 (IP-10), monocyte chemoattractant protein-1 (MCP-1), macrophage inflammatory protein $1 \mathrm{~A}$ (MIP-1A), monocyte chemotactic protein-3 (MCP-3), tumor necrosis factor alpha (TNF- $\alpha$ ), IL-6, and IL-1RA had been shown to associate with the pro-inflammatory profile $(5,90$, 93-97). Moreover, IL-6 levels have been directly corelated to viral loads (95). Also, increased IL-6 levels are detected before the intubation for mechanical ventilation $(98,99)$. IL-6 levels are linked to elevated IP-10, MCP-3, and IL-1RA levels and are associated with fatal outcomes $(95,100)$.

On the other hand, moderate pro-inflammatory cytokines have been observed in mild cases $(89,100)$, a finding not unique for SARS-CoV-2. Disease severity association with cytokine storm has been broadly studied for viruses such as the respiratory syncytial virus (RSV), which can lead to a cytokine storm syndrome in encephalitis cases (101), influenza A and B virus (102), and others coronaviruses including SARS-CoV (103) and MERS (104), Ebola virus, in hantavirus pulmonary syndrome (105, 106), and Epstein-Barr virus (107). A schematic representation for the contribution of cellular infiltration to disease is shown in Figure 3.

\section{Adaptive Cellular and Humoral Immunity Induced by SARS-CoV-2}

Lymphopenia is the most characteristic immune manifestation of patients infected with SARS-CoV-2 $(40,80,81,85)$. Subsets of $\mathrm{T}$ cells as $\mathrm{CD} 4^{+}, \mathrm{CD}^{+}$, and memory $\mathrm{T}$ cells are lower in severe cases, implying an inadequate antiviral response after SARSCoV-2 infection $(81,85)$. In this line, mild cases present an increase of $\mathrm{CD}^{+} \mathrm{T}$ cells until 11 days post-admission, which could be associated with the clinical outcome. Noteworthy, a case-report study shows that circulating $\mathrm{T}$ follicular helper cells (cTfh) progressively increased after 9 days post-admission during a mild disease and remain in peripheral blood during convalescent, consistent with antibody-secreting cells (ASC) (89). Together with corroborating the data described above, this study also showed the recruitment of ASC and cTfh cells in the blood of patients. These levels are slightly elevated when compared to healthy patients, even after 20 days of symptoms

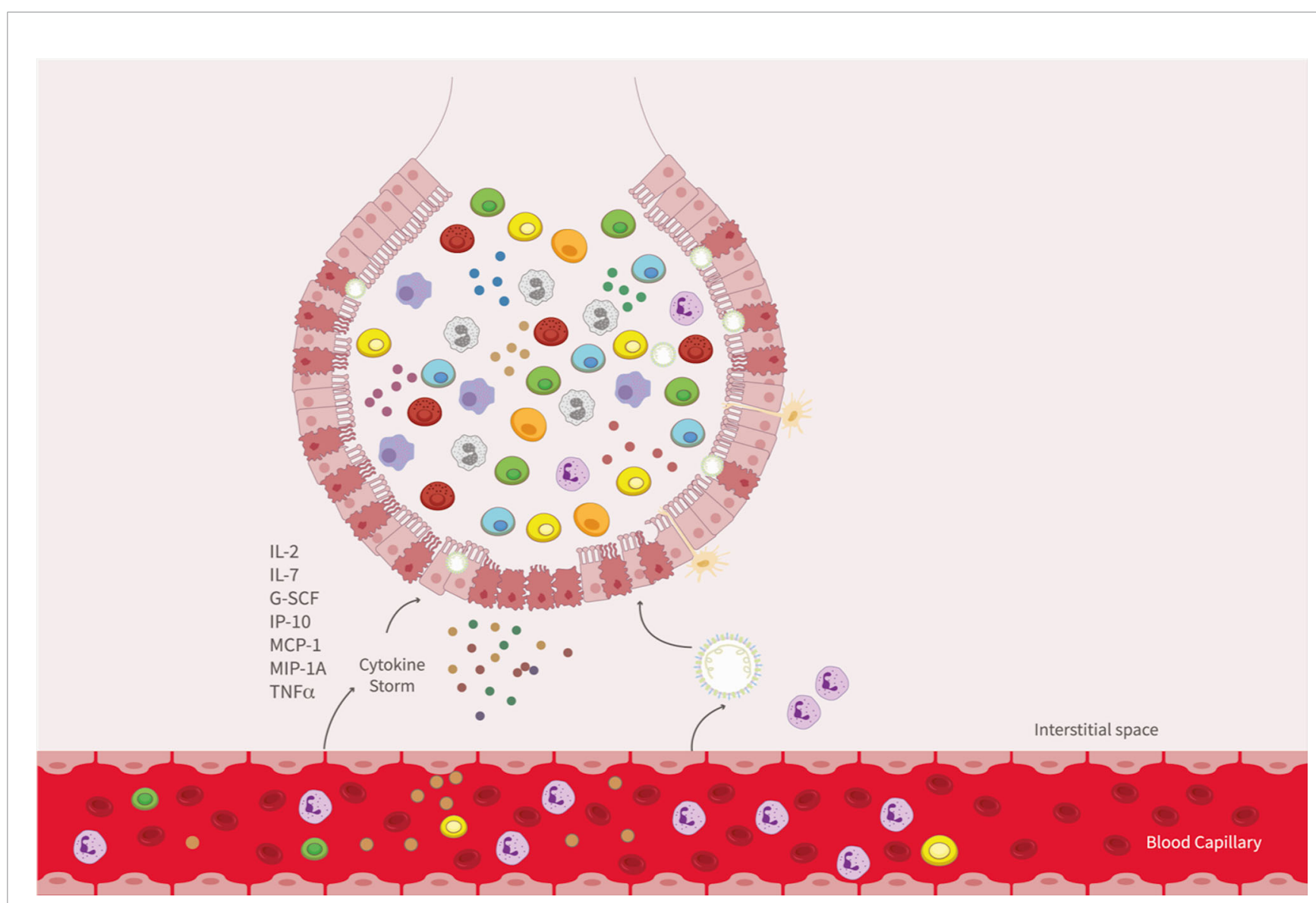

FIGURE 3 | Immune response against SARS-CoV-2. Cellular infiltration and Cytokines storm upon the infection of SARS-CoV-2. After SARS-CoV-2 recognition and replication in type II pneumocytes, peripheral blood cells are recruitment to alveoli, with a release of cytokines and chemokines (IL-2, IL-7, G-SCF, IP-10, MCP-1, MIP-1A, and TNF $\alpha$ ), allowing infiltration into the lung of granulocytes and mononuclear cells as monocytes, lymphocytes, and NK cells. Lungs-infiltrated cells are also involving in cytokines storm. 
onset (89). Tfh cell function is essential for developing memory B cells and the production of high-affinity antibodies (108). However, more studies are needed to better understand these interactions.

Consistent with this, a higher $\mathrm{B} / \mathrm{T}$ cell ratio has been found in COVID-19 patients $(81,89)$. In mild cases, the ASCs are detected after 7 days of post-admission in association with viral clearance (89). Also, in severe cases, ASCs levels are elevated compared to healthy controls, with a $31 \%$ expansion 7 days after the onset of the symptoms (109). No significant differences were observed for IgM and IgG production against SARS-CoV-2, with a peak from 7 days until 40 days post-admission independent of clinical course $(24,81,82,89,110)$. Also, it has been shown that IgG levels in asymptomatic patients were reduced when compared to symptomatic ones, in addition to a reduction in neutralizing antibody activity $(24,81)$. Along these lines, it was reported that only $19.3 \%$ of patients show a robust level of neutralization activity and that they decrease up to 28 days after their recovery, suggesting that neutralizing antibodies have a short halflife (111).

Studies reporting the immunophenotyping of the disease considered innate and adaptative responses, specifically, the neutrophil/lymphocyte ratio (NRL) and the IgG levels. A report, patients were separated into four groups: $\mathrm{NRL}^{\text {high }}$ IgG ${ }^{\text {high }}$; NRL ${ }^{\text {high }}$-IgG ${ }^{\text {low }}$; NRL ${ }^{\text {low }}$-IgG ${ }^{\text {high }}$ and NRL ${ }^{\text {low }}$-IgG ${ }^{\text {low }}$. The worse prognosis was found in both $\mathrm{NRL}^{\text {high }}$ groups, positively related to fatality. Remarkably, $\mathrm{NRL}^{\text {low }}-\mathrm{IgG}^{\text {low }}$ patients did not require mechanic ventilation (82). The NRL has been considered a reasonable and helpful measure to define disease severity in patients (112-115). This knowledge has been the key to identifying disease severity markers, which could contribute to defining therapeutic targets and for developing prophylactic strategies and vaccines.

\section{How the Immune Response Against SARS-CoV-2 Affects the Lung}

Due to the broad distribution of ACE2 molecule, SARS-CoV-2 infection could be displaying a multiorgan involvement (116). Nevertheless, the most frequently affected organ is the lung and an acute lung injury (ALI) can develop. Up to date, little is known about the mechanism involved in lung dysfunction. Histopathological analyses from deceased patients have revealed significant changes in the lung, highlighting the alveolar damage with desquamated pneumocytes, hyaline membrane, fibrinous exudate, and immune cell infiltration (117). Specifically, alveolar macrophages are found in the lumen and lymphocytes in the interstitium, associated with diffuse alveolar damage. The high infiltration controls the infection (84, 117-119), consistent with leukopenia in hemogram founded in affected patients. The diffuse damage in the lower respiratory tract could be due to infection in the Clara cells, a non-ciliated secretory type cell, and the evasion of an early immune response, such as interferon type I, allowing a high viral replication in the lower respiratory tract $(77,118,120)$.

During the infective process, the virus displays mechanisms to avoid the immune system of the host $(78,79)$. Once the innate immune cells recognize the viral particles, they become activated with the aim of clear the pathogen. Although peripheral myeloid cells play a crucial role during the innate immune response, little is known about their contribution during SARS-CoV-2 infection. Transcriptomic analyses performed in peripheral blood mononuclear cells (PBMC) and bronchoalveolar lavage fluid (BALF) samples from infected patients revealed a downregulation of genes related to degranulation and activation of immune cells, such as neutrophils in BALFs (121). Similar results were obtained from studies performed using necropsies $(88,92)$. On the hand, the expression of pro-inflammatory cytokines and chemokines is upregulated in BALFs of infected individuals (121). Remarkably, genes that encode for chemokine ligands (CCL)-2/MCP-1, CCL-3/MIP-1A, and CCL4/MIP-1ß, CXCL2, CXCL8 and CXCL10/IP-10 expression were increased in SARSCoV-2 patients, suggesting important recruitment of monocytes/ macrophages and neutrophils at lung during SARS-CoV-2 infection (121). These findings are consistent with the low levels of peripheral monocytes and lymphocytes that are associated with elevated expression of CCL8 and CCL2 and CXCL9 and CXCL16 in the blood of SARS-CoV-2 patients (77, $122)$, suggesting the migration of peripheral $\mathrm{T}$ cells to control the lung damage from the interstitium to the alveolar space (91). In addition, high levels of CXCL8 were detected in SARS-CoV-2 patients (77), which can promote the recruitment of granulocytes to the tissue and the production a pro-inflammatory environment in the alveoli $(123,124)$. One explanation for the damage of the airway epithelium is the recruitment of immune cells and the contribution of the degranulation to eliminate the infected cells, promoting an inflammatory state that can last until the viral clearance. As a result of this process, pulmonary damage is produced in a manner equivalent to other respiratory viruses $(94,125,126)$.

\section{VACCINES AND TREATMENTS}

\section{Vaccines}

Currently, the world science is focused on the development of a vaccine against SARS-CoV-2 (127). The need of developing vaccines during pandemic times represents a major challenge for science and medicine. First, SARS-CoV-2 is a new coronavirus strain, without a complete understanding of the best animal model for this infectious disease. Despite these difficulties, scientists worldwide work to advance with the highest possible velocity to develop and evaluate vaccine prototypes. Inactivated virus, DNAbased strategies, non-replicating viral vector, protein subunits, replicating viral vector, live attenuated virus, RNA-based, and VLPs are within the strategies being developed (128). In the last WHO report, 152 vaccines prototypes are being tested in preclinical models, and 42 are tested in humans, with ten of them in phase (129). Besides, until October 15, 2020, 10 studies, which showed immunogenicity and safety in previous phases, are in the early stages of Clinical Phase 3 (Table 1). As part of these phase 3 studies, between 30,000 and 65,000 volunteers have been recruited to evaluate these vaccine prototypes around the world (130).

The inactivated virus formulation has been broadly used for licensed vaccines being used for decades to prevent emerging 
TABLE 1 | Vaccine candidates for COVID-19 currently in clinical trials and their strategies.

\begin{tabular}{|c|c|c|c|c|c|}
\hline & Vaccine candidates & Phase I & Phase I/II & Phase II & Phase III \\
\hline $\begin{array}{l}\text { Non- } \\
\text { Replicating }\end{array}$ & ChAdOx1-S & & PACTR202006922165132 & $2020-001228-32$ & $\begin{array}{l}\text { ISRCTN89951424 } \\
\text { NCT04516746 }\end{array}$ \\
\hline \multirow[t]{5}{*}{ Viral Vector } & Adenovirus Type 5 Vector & ChiCTR2000030906 & & ChicTR2000031781 & NCT04526990 \\
\hline & Ad26COVS1 & & NCT04436276 & & NCT04505722 \\
\hline & Adeno-based (rAd26-S+rAd5-S) & NCT04436471 & & & NCT04530396 \\
\hline & & NCT04437875 & & & \\
\hline & $\begin{array}{l}\text { Replication defective Simian Adenovirus (GRAd) } \\
\text { encoding S }\end{array}$ & NCT04528641 & & & \\
\hline \multirow[t]{7}{*}{ Inactivated } & CoronaVac & & NCT04383574 & & NCT04456595669/ \\
\hline & & & NCT04352608 & & UN6.KEP/EC/2020 \\
\hline & Inactivated & & ChiCTR2000031809 & & ChiCTR2000034780 \\
\hline & Inactivated & & ChiCTR2000032459 & & ChiCTR2000034780 \\
\hline & Inactivated & NCT04412538 & NCT04470609 & & \\
\hline & Inactivated & & NCT04530357 & & \\
\hline & Whole-Virion Inactivated & & NCT04471519 & & \\
\hline Protein & Adjuvanted recombinant protein (RBD-Dimer) & NCT04445194 & & NCT04466085 & \\
\hline \multirow[t]{9}{*}{ Subunit } & $\begin{array}{l}\text { Full length recombinant SARS CoV-2 } \\
\text { glycoprotein nanoparticle vaccine adjuvanted } \\
\text { with Matrix M }\end{array}$ & & NCT04368988 & & \\
\hline & RBD-based & & NCT04473690 & & \\
\hline & $\begin{array}{l}\text { Native like Trimeric subunit Spike Protein } \\
\text { vaccine }\end{array}$ & NCT04405908 & & & \\
\hline & $\begin{array}{l}\text { Recombinant spike protein with Advax }{ }^{\mathrm{TM}} \\
\text { adjuvant }\end{array}$ & NCT04453852 & & & \\
\hline & $\begin{array}{l}\text { Molecular clamp stabilized Spike protein with } \\
\text { MF59 adjuvant }\end{array}$ & ACTRN12620000674932p & & & \\
\hline & S-2P protein + CpG 1018 & NCT04487210 & & & \\
\hline & RBD + Adjuvant & IFV/COR/04 & & & \\
\hline & $\begin{array}{l}\text { RBD (baculovirus production expressed in Sf9 } \\
\text { cells) }\end{array}$ & ChiCTR2000037518 & & & \\
\hline & Peptide (EpiVacCorona) & NCT04527575 & & & \\
\hline $\begin{array}{l}\text { Virus like- } \\
\text { particles }\end{array}$ & $\begin{array}{l}\text { Plant-derived VLP adjuvanted with GSK or } \\
\text { Dynavax adjs. }\end{array}$ & NCT04450004 & & & \\
\hline \multirow[t]{7}{*}{ RNA } & LNP-encapsulated mRNA & NCT04283461 & & NCT04405076 & NCT04470427 \\
\hline & 3 LNP-mRNAs & & 2020-001038-36 & & NCT04368728 \\
\hline & & & ChiCTR2000034825 & & \\
\hline & mRNA & NCT04449276 & & NCT04515147 & \\
\hline & mRNA & & NCT04480957 & & \\
\hline & LNP-nCoVsaRNA & ISRCTN17072692 & & & \\
\hline & mRNA & ChiCTR2000034112 & & & \\
\hline \multirow[t]{6}{*}{ DNA } & DNA plasmid vaccine with electroporation & & NCT04447781 & & \\
\hline & & & NCT04336410 & & \\
\hline & DNA plasmid vaccine + Adjuvant & & NCT04463472 & & \\
\hline & & & NCT04527081 & & \\
\hline & DNA plasmid vaccine & & CTRI/2020/07/026352 & & \\
\hline & DNA Vaccine (GX-19) & & NCT04445389 & & \\
\hline Replicating & Measles-vector based & NCT04497298 & & & \\
\hline Viral Vector & & & & & \\
\hline
\end{tabular}

respiratory diseases (131). Phase $1 / 2$ clinical trials revealed the safety of using an inactivated vaccine against SARS-CoV-2 with a range of adverse reactions between $20 \%$ and $30 \%$ of those vaccinated and a robust neutralizing response after the second dose (132-134).

An inactivated vaccine generated by Sinovac (CoronaVac) was evaluated pre-clinically rats, mice and rhesus macaques, with two doses, on days 0 and 7 days after challenge, secretion of IgG of $10^{5}$ approximately 1 week after immunization against the SARS-CoV-2 S-protein important to obtain a robust IgG secretion. Consistently, neutralization assays were carried out. A high titer of neutralized antibodies ( $1 \times 10^{4}$ approximately) is observed 6 weeks after immunization, the results are similar for clinical phase 1 and 2 study with two doses at 0 and 14 days (133, 134). Also, Coronavac has not shown significant severe adverse reactions in Phases 1 and 2. Thus, this vaccine has moved on to a Phase 3 clinical trial (135).

The inactivated vaccine developed by Sinopharm evaluated in Phases 1 and 2 clinical trials was administrated intramuscularly in two doses (5 ug/dose) at 0 and 21 days. According their interim reported showed high titers of neutralized antibodies in volunteers, $1 \times 10^{3}$ approximately (132). Currently, this vaccine is in Phase 3 (135).

$\mathrm{BBIBP}-\mathrm{CorV}$ is an inactivated prototype of a vaccine against SARS-CoV-2 tested in six clinical models (including mice, rats, guinea pigs, rabbits, and nonhuman primates), which were 
immunized intramuscularly route twice on days 0 and 21 . These mammalian species were challenged with SARS-CoV-2; the vaccine-induced high levels of neutralizing antibodies do not produce significant adverse effects in the biochemical serum parameters. Furthermore, it was observed that immunization with two doses with $2 \mathrm{ug} /$ dose of BBIBP-CorV conferred significant protection against SARS-CoV-2 (136).

Adenovirus-based vaccines are led by AstraZeneca, CanSino Biologics Inc, Gamaleya Research Institute, and Janssen Vaccines \& Prevention B.V (130). AstraZeneca produced a chimpanzee adenovirus-vectored vaccine (ChAdOxl nCoV-19) in their report indicated the vaccine was tolerated with $1 \mathrm{~g}$ of paracetamol every $6 \mathrm{~h}$, which must be administered prophylactically $24 \mathrm{~h}$ before vaccination (137). The response of IgG antibodies against the SARS-CoV-2 protein S reached a peak on day 28 and was maintained until day 56 after vaccination. Furthermore, the IFN- $\gamma$ response peaked at day 14 and antibodies capable of neutralizing live SARS-CoV-2 were induced on day 28 after a booster dose (137). The Phase 3 clinical trial of this vaccine prototype was paused to allow the review of data by an independent committee, due to a suspected severe adverse reaction in two different patients. After this review, the trial was restarted in India, Brazil, and the UK (138).

CanSino Biologics INC developed a prototype with recombinant adenovirus type 5 (Ad5) called rAd26-S + rAd5$\mathrm{S}$, which expresses the $\mathrm{S}$ glycoprotein of SARS-CoV-2. In phase $1 / 2$ studies it was shown that the vaccine is safe, well-tolerated, with the majority of adverse reactions of mild or moderate severity which include fever (46\%), headache (39\%), fatigue (44\%), vomiting $(2 \%)$, loss of appetite $(16 \%)$, diarrhea $(11 \%)$, and occur in the first 7 days post-vaccination. In general, this vaccine induced a strong humoral and cellular immune response in healthy patients, which begins to be observed 14 days postvaccination. Secretion of IFN- $\gamma$, TNF- $\alpha$, and IL- 2 by CD $4^{+}$and $\mathrm{CD}^{+} \mathrm{T}$ cells was measured, and a peak was observed at day 28 th post-vaccination). A single dose of the COVID-19 vaccine vectorized with Ad5 caused a four-fold increase in RBDbinding antibodies and virus neutralization (139). Due to the success of this prototype, it had advanced to a Phase 3 clinical study (129).

A preliminary report from a phase 1 for a mRNA-based vaccine against SARS-COV-2 (mRNA-1273) indicated that seroconversion appears on day 15 after the first vaccination (140). Also, antibody neutralizing activity was detected after the second vaccination (140). A report of phase $1 / 2$ of RNA vaccine BNT162b1 indicated that the candidate elicited a higher titer of $\mathrm{nAb}$ than the convalescent group, with a temporal decrease of lymphocytes that return to baseline levels between 1 week (141). No data for T and B cell immunity have been reported yet (141).

Subunit vaccines used protein-S, and RBD subunits since $S$ protein must have a stable domain $(142,143)$. It was shown that spike-immunized mice developed a virus neutralizing antibody response that lasted for 10 weeks approximately (144). Novavax designed a prototype with an innovative adjuvant Matrix-M1 adjuvant, a positive correlation between the immunization dose mixed with adjuvant with the production of neutralized antibodies was obtained (145). Also, this prototype is evaluated in Phase 3 (138).

The recombinant viral vector methodology has been widely studied for the development of vaccines and gene therapy (146). Viral vectors used for this strategy are measles virus, poxvirus, adenovirus, and vesicular stomatitis virus (147). This type of prototype has been widely studied with adenoviruses since they can induce a population of $\mathrm{CD}^{+}$and $\mathrm{CD}^{+}$cells $(148,149)$. For SARS-CoV-2, this vaccination strategy has used the vesicular stomatitis virus (VSV) with replicative capacity, which expressed a modified form of the S-gene of SARS-CoV-2. This preliminary study demonstrated a decrease in viral load in mice immunized with two doses of VSV-eGFP-SARS-CoV-2 and challenged with SARS-CoV-2, at 4 days post-infection in samples of lung, splenocytes, heart, and nasal lavage, in addition to high IgG secretion (150).

\section{Trained Immunity and SARS-CoV-2 Infection}

Trained immunity is based on acquiring a type of immune memory by epigenetic reprogramming of innate immune cells, such as monocytes and NK cells $(151,152)$. It has been observed that the tuberculosis vaccine consisting of an attenuated mycobacteria Bacillus Calmette-Guerin (BCG) produces a long-lasting trained immunity consisting of these innate cell populations (153-157). It has been hypothesized that BCGvaccination could associate with decreased disease severity and lethality during COVID-19 worldwide (158). The lethality reported by COVID-19 in countries with BCG vaccination is about 5.8 times lower than countries without the BCG vaccination program (159). Equivalent suggestions have been made by other studies supporting the notion of using the BCG vaccine to prevent severe COVID-19 at least in the most vulnerable groups, such as the elderly and healthcare personnel $(160,161)$. Recently, a study in a hospital from the United Arab Emirates demonstrated that a boost with the BCG vaccine in the healthcare workers could reduce the disease caused by SARSCoV-2 (162).

However, clinical trials are needed to scientifically define the impact of BCG vaccine as a preventive measure for COVID-19. Along these lines, since WHO declared a pandemic for SARSCoV-2, more than 21 clinical trials are currently in progress to evaluate whether BCG vaccination in adults and healthcare workers could decrease the symptoms caused by COVID-19 (163). Some of these first clinical trials were performed in the Netherlands (NCT04328441) and Australia (NCT04327206) as phase III clinical trials (163). In addition, one phase IV clinical trial is in progress (NCT04417335).

Despite the promising results of BCG vaccination, up to date there are not yet published data demonstrating the benefits of the BCG vaccine in clinical trials. Moreover, the WHO did not recommend the BCG vaccine as an approach for COVID-19 (164). It is likely that the WHO decision was based on the lack of direct clinical evidence supporting a benefit for SARS-CoV-2 infection and that an increased demand for the BCG vaccine could jeopardize the supply for tuberculosis rates vaccination (164). 


\section{Therapeutic Approaches for SARS-CoV-2 Infection}

The design of therapeutic strategies for COVID-19 has been oriented in three fundamental directions: viral elimination using molecules that can interfere with viral replication, antiinflammatory therapies, or palliative treatments that help reduce symptoms and the regulation of the immune response (165). The COVID-19 emergency had challenged researchers to design treatments. In the meantime, clinicians have given some already registered drugs to reduce disease severity in patients.

Furthermore, recent findings suggest that clinical recovery can be promoted by the administration of antiviral therapy before lung disease is at an advanced stage $(166,167)$. In this section, some drugs and other therapeutic strategies under evaluation will be described. A summary of the therapeutic approaches is described in Table 2 .

\section{A) Antivirals}

Remdesivir is a nucleotide analog that works as an inhibitor upon binding to the viral RNA strands and disrupts new the synthesis viral genomes with successful results against coronaviruses as SARS-CoV MERS-CoV, is currently tested for SAR-CoV-2 $(168,194)$. In vitro studies in Vero E6 cells have shown that Remdesivir inhibits the replication of SARS-CoV-2 after entry into the cells (168). Medical reports published by China and the United States indicate a faster recovery of patients in response to the administration of Remdesivir (92, 169). Recently, the Food and Drug Administration (FDA) authorized this drug for severely hospitalized COVID-19 patients (195). Later, the FDA approved the use of Remdesivir in hospitalized patients with confirmed or suspected COVID-19, regardless of severity, based on the results in a controlled clinical trial including hospitalized patients with mild, moderate, and severe disease (NCT04280705).

Favipiravir is a purine nucleic acid analog previously used to treat influenza, considered a prodrug whose active metabolite interferes with viral replication by inhibiting viral RNA polymerase $(170,191)$. In a clinical trial (ChiCTR2000029600), the administration of Favipiravir combined with interferon $-\alpha$ $($ IFN- $\alpha$ ) in patients with COVID-19, contributes to an enhanced viral clearance (171).

Lopinavir and ritonavir are protease inhibitors used in the therapy for human immunodeficiency virus 1.(HIV-1) (196). SARS-CoV-2 patients treated with these drugs showed only a slight improvement $(4,5,197)$. The combination of lopinavirritonavir with ribavirin and IFN $\beta / 1 \mathrm{~b}$ reduced viral loads in nasopharyngeal swabs, stool, and saliva obtained from patients after 8 days of treatment (198). Notably, IL-6 levels decreased significantly after treatment with this combined antiviral treatment (174). These observations suggest that an early treatment with these drugs can decrease virus spread and reduce the exacerbated production of pro-inflammatory cytokines (198).

Arbidol is a derivative of indole, which acts on aromatic amino acids and can interfere with the replication of the influenza virus (199). In vitro studies on SARS-CoV-2 have shown that Arbidol can block the entry and trafficking to intracellular vesicles (176). Arbidol reduces the risk of developing lung lesions when used alone or together with lopinavir/ritonavir to promote viral elimination without significant side effects (200-202). Additionally, the mix of antivirals and interferon was shown to efficiently reduce both

TABLE 2 | Treatments under evaluation for COVID-19 and their mechanisms of action.

\begin{tabular}{|c|c|c|c|}
\hline & Treatments & Action Mechanisms & Limitations \\
\hline \multirow[t]{4}{*}{ Antivirals } & Remdesivir & Viral replication inhibitor (168) & $\begin{array}{l}\text { Bradycardia, liver damage, and } \\
\text { gastrointestinal reactions that can contribute } \\
\text { to the deterioration of the disease (169). }\end{array}$ \\
\hline & Favipiravir & Inhibits viral RNA polymerase (170). & $\begin{array}{l}\text { Gastrointestinal disorders, skin lesions, liver, } \\
\text { and cardiovascular damage }(168,171) \text {. }\end{array}$ \\
\hline & Lopinavir-ritonavir & $\begin{array}{l}\text { Protease inhibitor believed to interfere with viral fusion with cell membrane (172, } \\
\text { 173). }\end{array}$ & $\begin{array}{l}\text { Antiviral activity against SARS-CoV-2 has not } \\
\text { been found in clinical studies }(174,175) \text {. }\end{array}$ \\
\hline & Arbidol & Blocks entry and intracellular traffic in vesicles (176). & $\begin{array}{l}\text { Some patients may develop hypersensitivity } \\
\text { (176). }\end{array}$ \\
\hline \multirow[t]{6}{*}{$\begin{array}{l}\text { Other } \\
\text { drugs }\end{array}$} & $\begin{array}{l}\text { Chloroquine and } \\
\text { hydroxychloroquine }\end{array}$ & Immunomodulatory effect. It is inhibiting the entry of SARS-CoV-2 $(168,177-179)$. & $\begin{array}{l}\text { Accumulation in various organs and low } \\
\text { elimination rate; and arrhythmia and heart } \\
\text { failure }(178,180,181) .\end{array}$ \\
\hline & Melatonin & Inhibits calmodulin $(182,183)$ & $\begin{array}{l}\text { This would only allow reducing the } \\
\text { associated clinical symptoms (183). }\end{array}$ \\
\hline & Dexamethasone & $\begin{array}{l}\text { Reduce the duration of mechanical ventilation and mortality from severe acute } \\
\text { respiratory distress syndrome (184). }\end{array}$ & There are only a palliative treatment (184). \\
\hline & Plasma Treatment & Neutralizing antibodies against SARS-CoV-2 (185). & $\begin{array}{l}\text { Doses dependent on the neutralizing title } \\
\text { (186). }\end{array}$ \\
\hline & $\begin{array}{l}\text { Specific monoclonal } \\
\text { antibodies to SARS- } \\
\text { CoV-2 }\end{array}$ & $\begin{array}{l}\text { Blocks the entry of the virus through ACE2 because they are mainly directed against } \\
\text { the S protein }(187-190)\end{array}$ & $\begin{array}{l}\text { Although several mAbs have been evaluated } \\
\text { in vitro, in vivo, and there are ten clinical trials } \\
\text { ongoing }(166,170,171,191)\end{array}$ \\
\hline & Tocilizumab & $\begin{array}{l}\text { Non-specific Abs for SARS-CoV-2. This directed against IL-6 receptor, IL-6 is one } \\
\text { of the cytokines responsible for the inflammatory state persistent in severe patients } \\
(192,193) \text {. }\end{array}$ & $\begin{array}{l}\text { It has been reported only beneficial effects in } \\
\text { critically ill patients }(82,193) \text {. }\end{array}$ \\
\hline
\end{tabular}


symptoms and viral loads (203). Currently, a clinical study is evaluating the safety and efficacy of Arbidol as an adjuvant for an antiviral therapy combined with IFN $\beta / 1 \mathrm{a}$ in SARS-CoV-2 positive patients (NCT04350684).

The main restriction of antiviral treatments is the development of adverse effects, such as liver and cardiovascular damage, gastrointestinal disorders, and skin lesions, which are the most commonly reported for the antivirals mentioned above and could worsen the patient condition $(168,169,171)$.

\section{B) Aminoquinolines}

Chloroquine and its hydroxychloroquine analog are antimalarials that have been used for over 50 years as a prophylaxis and treatment (204). Both drugs lead to a reduction of MHC class II expression, the production of reactive oxygen species (ROS) and proinflammatory cytokines, such as IL-1 $\beta$ and TNF- $\alpha$ (204). Additionally, hydroxychloroquine can enter lysosomes, impairing the acidification mechanisms and the function of these organelles (205).

Previous data from in vitro studies showed that chloroquine can display an antiviral capacity against Chikungunya virus (CHIK) and SARS-CoV $(177,206)$. Furthermore, chloroquine was shown to be able to inhibit the entry of SARS-CoV-2 into Vero E6 cells at concentrations that do not cause cytotoxic effects in vivo (168). Due to these results, both drugs were applied as treatment to COVID-19 patients worldwide, with a constant debate about effectiveness (207). However, later on during the pandemic, WHO suspended all clinical trials testing these compounds for COVID-19, as no significant improvements were found in treated patients. Furthermore, one clinical study showed a high fatality rate $(63.6 \%)$ due to high hydroxychloroquine doses, which can cause cardiac toxicity (180, 181, 208).

\section{C) Melatonin}

$\mathrm{N}$-acetyl-5-methoxytryptamine (or melatonin) is a derivative of tryptophan, an essential amino acid that plays a critical role in immuno-inflammatory events produced during a viral infection. Besides, melatonin acts as an antioxidant that reduces oxidative stress and reduces vascular permeability (209-212). The use of this molecule use has increased in atherosclerosis and respiratory distress, such as acute lung disease, viral or bacterial infections (209-212). Melatonin alleviates respiratory pain by reducing vascular permeability and can inhibit calmodulin, an essential protein for ACE2 function (182). Because melatonin indirectly targets various cellular targets of SARS-CoV-2, including the ACE2, the use of this molecule against SARS-CoV-2 infection has been suggested $(183,213)$. Currently, six clinical studies are evaluating the effectiveness and safety of melatonin as prophylaxis, both in critically ill and outpatients (NCT04474483, NCT04531748, NCT04409522, NCT04353128, NCT04530539, NCT04470297). Two of these clinical studies are currently in the recruitment phase, the first plans to evaluate the antiinflammatory effects of melatonin in a patient with COVID-19 (NCT04409522). The second takes advantage of the antiinflammatory effects of melatonin to proposed it as prophylaxis for health care workers (NCT04353128). However, it must be considered that this drug does not inhibit viral replication and transcription. Instead, the administration of melatonin only reduces the associated clinical symptoms (182, 214).

\section{D) Dexamethasone}

Dexamethasone is a corticosteroid that has been shown to reduce the duration of mechanical ventilation and fatality caused by COVID-19 (215). The use of corticosteroid for the management for acute respiratory distress syndrome due to viral infections is a controversial topic since these drugs can delay the elimination of the virus and increase the risk of secondary infections due to their immunosuppressive effect. Despite this, it has been used successfully to treat influenza A (H1N1) pdm09-associated pneumonia, reducing mortality (216). Thus, dexamethasone can be used as a treatment combined with other antiviral or drug therapy $(186,215,217)$.

\section{E) Immune Therapies \\ i) Plasma Transfusion}

Transfusion of plasma is used for acute infections and is a classic form of immunotherapy for emerging infectious-diseases (218). This therapy is based on the passive administration of plasma with high titers of nAbs, generated endogenously by convalescent individuals (219). Such a therapy is still in use and has been implemented successfully in diseases without a favorable treatment or specific vaccine (187). During the last epidemics due to Ebola (EBOV), Influenza A-H1N1, and emerging coronaviruses, this type therapy has been implemented as an alternative for treatment (220-223).

Mainly, transfer of plasma from convalescent patients after SARS-CoV or MERS infections showed viral loads reduction and improvement of clinical and laboratory parameters, with a decrease in temperature, increased oxyhemoglobin saturation, improved lymphocyte levels, and decreased C-reactive protein levels. Also, fresh frozen plasma (FFP) improves survival rates in patients $(186,224)$. Similarly, recovery from COVID-19 disease was observed in patients with severe illness after treatment with convalescent plasma with high nAbs titters obtained from surviving donors (185). Importantly, during an FFP treatment, other biological products involved in the recovery of patients, such as anti-inflammatory cytokines and defensins, are also transferred (225). The principal limitation of FFP is to determine the optimal $\mathrm{nAb}$ titer required for an efficient virus neutralization (186). Thus, hemovigilance is essential because some patients could need more than one dose of FFP depending on the severity of illness, as described for other viral diseases where plasma transfusion was utilized (226). Moreover, the use of FFP has equivalent risks for adverse effects than any other blood component transfusion, such as allergic/anaphylactic reaction and infections due of other microbes (226).

Nevertheless, the reported incidence of adverse reactions after transfusion of convalescent plasma is less than 5\% (227). One of the precautions to consider is avoiding Transfusion Related Acute Lung Injury (TRALI) $(218,227)$. TRALI is a new acute lung injury and occurs during or within $6 \mathrm{~h}$ after transfusion 
$(218,228)$. TRALI-patients present acute dyspnea, need of intubation, hypertension, hypotension, and acute leukopenia $(218,228)$. To prevent acute lung injury, it has been recommended to transfer the plasma to patients who have never been pregnant or undergone an abortion, thus allowing to decrease the possibility of presenting the antibodies to HLA or granulocyte antigens in the serum that could lead to the development of TRALI $(218,229)$.

The half-life of antibodies determinates the election for the plasma donor (226). Yet, researchers have not determined the reduction of viral loads in severe COVID-19 patients with convalescent plasma treatment (CPT) or FFP and mixture with antiviral treatments $(187,224,230)$. Furthermore, given that the population at risk includes patients with comorbidity such as hypertension, diabetes, or cardiovascular diseases, which are part of potential CPT donors, makes it challenging to validate CPT as one of the therapies that should be considered on a larger scale (224, 230, 231).

Despite all these questions, both advantages and disadvantages of the therapy should be taken into consideration for treatment of SARS-CoV-2 infection. Based on history and evidence, and due to the health emergency, CTP is currently used throughout the world and was recently approved by the FDA, with guidelines for healthcare professionals $(232,233)$.

\section{ii) Monoclonal Antibodies}

Monoclonal antibodies (mAbs) are a powerful tool for treating of several diseases, such as cancer and immunological illnesses (234). Along these lines, various strategies are in progress to isolate different mAbs specific for various SARS-CoV-2 antigens, due the potential of $\mathrm{mAbs}$ against emerging viruses (192, 235). Further, the use of mAbs against other emerging viruses has demonstrated potent neutralizing effects for SARS$\mathrm{CoV}$ and MERS-CoV $(234,236)$. Since mAbs have been previously tested as prophylactics for SARS, using $\mathrm{mAb}$ to prevent SARS-CoV-2 infection stands as a promising approach to treat or prevent this disease, at least in the most susceptible individuals $(235,237)$. Additionally, mAbs could be used as treatment against viral encephalitis, and their use might help reduce not only respiratory symptoms by also neurological symptoms (238). For this reason, several groups are working on the development of this therapy for COVID-19 using various strategies.

Human recombinant soluble ACE2 (hrsACE2) blocks the viral entry in vitro, decreasing viral loads, however, in vivo, hrsACE2 failed to block viral entry (192). Other strategies involve the development of mAbs from SARS-CoV-2 convalescent individuals and $206 \mathrm{mAbs}$ were recently isolated from eight of them. Although two of those antibodies blocked viral entry, their specificity and neutralizing activity requires further characterization (239). More recently, a new mAb was discovered called MAb362, which is a cross-reactive human IgA $\mathrm{mAb}$ that was shown capable to neutralize SARS-CoV-2 in vitro. This $\mathrm{mAb}$ also targets the $\mathrm{S}$ protein and prevents the binding with the ACE2 receptor (235).

Similarly, nineteen nAbs that target the RBD or the $\mathrm{N}$ terminal domain (NTD) from the $\mathrm{S}$ protein were isolated from convalescent patients (240). All the antibodies demonstrated an impressive capability of neutralizing SARS-CoV-2 in vitro, making them good candidates for clinical evaluation (240). Additionally, the isolation of neutralizing mAbs against SARSCoV-2 from convalescent patients of COVID-19 led to the identification of two mAbs, CA1, and CB6. While both showed in vitro the capacity to neutralize the virus, CB6 outperformed CA1. Studies in the rhesus macaque model showed decreased viral loads due to intravenous vaccination at a dose of $50 \mathrm{mg} / \mathrm{kg}$ with CB6. Furthermore, a single dose of CB6 prophylaxis before exposure to SARS-CoV-2 demonstrated protection in macaques against infection (241).

REGN-COV2 is an anti-viral antibody cocktail, which is composed by anti-spike antibodies that target the RBD of the protein (242). This cocktail has the potential of being used as prevention as well as a treatment for patients with COVID-19 $(242,243)$. Currently, REGN-COV2 is being evaluated in clinical trials as a treatment for non-hospitalized and hospitalized COVID-19 patients, and as prevention for the high-risk group of people (243).

Other mAbs have been tested in patients with COVID-19, such as tocilizumab, an IL-6 receptor-specific mAb that was evaluated in at least one clinical trial (ChiCTR2000029765) showing beneficial effects in a cohort with severe COVID-19. Also, these mAbs were recommended for patients with low IgG levels and high NLR (82). Nonetheless, adverse effects reported included increased hepatic enzymes (transaminases), thrombocytopenia, neutropenia, cutaneous rash and infections in the bloodstream. Other side effect were bacteremia and fungemia, which were likely the result of the IL-6 inhibition, which can impair $\mathrm{B}$ and $\mathrm{T}$ cell proliferation and function and diminish the immune response against infection agents (244). Furthermore, mAbs capable of neutralizing pro-inflammatory cytokines could be applied to prevent or reduce the cytokine storm $(82,193)$.

Few studies are ongoing to identify and obtain mAbs against SARS-CoV-2, such as the NCT04342195 and NCT04354766. More than ten clinical trials evaluating the effectiveness of mAbs as a treatment against this virus are in progress (245). Within the first trials are the involved the use of TJ003234 (NCT04341116), gimsilumab (NCT04351243), and lenzilumab (NCT04351152), which are mAbs against granulocyte macrophage-colony stimulating factor (GM-CSF). The last one is currently in phase III clinical trial (245). Other phase III trials in progress are REGN-COV-2 (NCT04452318) that has three different targets in the $\mathrm{S}$ protein, thus preventing the virus from entering into the cell, and LY-CoV555 (NCT04497987) that comes from a patient now recovered from SARS-CoV-2 (246). Although no results have been published up to date, these mAbs seem as promising approaches for preventing or treating COVID-19.

\section{iii) Single-Domain Antibodies}

Heavy chain antibodies are derived naturally from camelids (247, 248). Their lack of variable region has a smaller size than conventional antibodies, with high stability and affinity for each respective cognate epitope $(247,248)$. Therefore, the 
isolation of a camelid-derived single domain antibody ( $\mathrm{SdAb}$ ) is considered a new promising therapeutic strategy (248). Similar to mAbs, the therapeutic mechanism is focused on the virus neutralizing activity. For this reason, SARS-CoV-2 is mainly directed against RBD, blocking the union with the ACE2 receptor. A SdAb called $\mathrm{H} 11$ was identified with a higher affinity, neutralizing activity and a $K_{D}<1 \mu \mathrm{M}$ (249). Similarly, a SdAb called Ty1 was isolated from an alpaca after immunization twice with SARS-CoV-2 S1-sheep-Fc and the other two with SARS-CoV-2 RBD region in a 60 days scheme (247).

\section{CONCLUDING REMARKS}

Even though it has been more than 6 months since discovering this novel coronavirus, the knowledge of the immune response elicited against SARS-CoV-2 remains scarce. So far, it has been proposed that the immune response is a major component of the pathology observed during COVID-19.

The reduction of $\mathrm{T}$ cells in peripheral blood during SARSCoV-2 infection could lead to an inadequate memory response, similar to what is described for other viral infections (81). It has been proposed that a limited presence of eosinophils, monocytes, and $\mathrm{T}$ cell subsets in peripheral blood might be due to the large recruitment of those cells to the lung epithelium after infection (Figure 3) (92). Consistently with this notion, it was shown that SARS-CoV and MERS impaired the host memory immune response (250). Although, the long-lasting immune response cannot be elucidated yet, a vaccine for SARS-CoV-2 is expected to promote long lasting immunological memory (251-253).

Furthermore, there are still many unknown elements of the immune response induced by SARS-CoV-2. The severe clinical cases have allowed us to begin understanding the development of SARS-CoV-2 infection in the host. Despite this, many questions have arisen about the immunopathology and as to how it can relate to pre-existing chronic diseases and severe clinical manifestations, even death in young people. Up to date, the number of lymphocytes and neutrophils have been suggested as markers of disease severity (254). As described above, several studies have revealed symptoms involving the CNS during COVID-19 disease. However, it has not yet been defined the mechanism for viral entrance in CNS. Additional studies are needed to explain as to how cytokine storm is associated to disease severity and patient with the outcome.

Scientific efforts to design therapies are essential to prevent acute respiratory deterioration, the use of ventilation, morbidity, and mortality from SARS-CoV-2 infection. Although during the pandemic, significant progress on vaccine development has been made, still no safe and efficacious vaccine is available for the use of the population. The fact that several of prototypes are currently starting phase III clinical trial evaluation (Table 1) provides hope for an availability of vaccine for COVID-19 much sooner than for any other infectious disease. Furthermore, production of mAbs could be a parallel strategy for COVID19 prophylaxis.

It seems likely that an unbalanced immune response triggered by SARS-CoV-2 infection requires that the therapeutic interventions described above not only aim at eliminating the virus but also at regulating the immune response to prevent the exacerbated inflammation observed during COVID-19 (255). The antivirals target different steps of viral replication, the combination of which could be useful to limiting viral loads and the subsequent spread of the virus, promoting an effective antiviral response by $\mathrm{T}$ cells $(10,11)$. The combination of antiviral therapies with interferon can be beneficial to control viral spread (256). In addition, some antiviral drugs are capable of activating a cellular immune response on its own, stimulating the secretion of virus-specific antibodies and activating adaptive immunity $(170,257)$. Finally, blocking the pro-inflammatory cytokine response is another crucial point for the design of therapeutic strategies to improve critically ill patients (82).

The search for a vaccine is an urgent need at a global level. Nowadays, technologies have allowed us to work by leaps and bounds searching for new vaccines or therapies against SARS$\mathrm{CoV}-2$. It is necessary to prioritize the health of volunteers and ensure the safety of vaccine prototypes, especially since the variety of potential adverse effects have not been fully understood yet, such as the antibody-dependent enhancement $(\mathrm{ADE})$, which stands as a risk of vaccination or immunotherapy. A full study regarding all the possible adverse effect is needed, as well as the transparency of the clinical studies that are carried out.

\section{AUTHOR CONTRIBUTIONS}

GC-M designed, wrote, and revised the manuscript, and designed the figures. FS wrote, revised, and edited the manuscript. CA wrote, revised, and edited the manuscript. MO and CR wrote and revised the manuscript. LR-G and RB wrote and drew the figures. $\mathrm{AK}$ is the leading investigator and supported in the organization and full manuscript revision. All authors contributed to the article and approved the submitted version.

\section{FUNDING}

This work was supported by FONDECYT 1190830, FONDEF D11I1080, Millennium Institute on Immunology and Immunotherapy (P09/016-F, ICN09_016), Fundación COPECUC, Regional Government of Antofagasta through the Innovation Fund for Competitiveness FIC- R 2017 (BIP Code: 30488811-0). Biomedical Research Consortium Chile (13CTI21526/P4). AK is a Helen C. Levitt visiting professor at the Department of Microbiology and Immunology of the University of Iowa. 


\section{REFERENCES}

1. Coronaviridae Study Group of the International Committee on Taxonomy of Viruses. The species Severe acute respiratory syndrome-related coronavirus: classifying $2019-\mathrm{nCoV}$ and naming it SARS-CoV-2. Nat Microbiol (2020) 5:536-44. doi: 10.1038/s41564-020-0695-Z

2. Chan JF-W, Kok K-H, Zhu Z, Chu H, To KK-W, Yuan S, et al. Genomic characterization of the 2019 novel human-pathogenic coronavirus isolated from a patient with atypical pneumonia after visiting Wuhan. Emerg Microbes Infect (2020) 9(1):221-36. doi: 10.1080/22221751.2020.1737364

3. Benvenuto D, Giovanetti M, Ciccozzi A, Spoto S, Angeletti S, Ciccozzi M. The 2019-new coronavirus epidemic: Evidence for virus evolution. J Med Virol (2020) 92(4):4559. doi: 10.1002/jmv.25688

4. Xu X, Chen P, Wang J, Feng J, Zhou H, Li X, et al. Evolution of the novel coronavirus from the ongoing Wuhan outbreak and modeling of its spike protein for risk of human transmission. Sci China Life Sci (2020) 63(3):45760. doi: 10.1007/s11427-020-1637-5

5. Huang C, Wang Y, Li X, Ren L, Zhao J, Hu Y, et al. Clinical features of patients infected with 2019 novel coronavirus in Wuhan, China. Lancet (2020) 395:497-506. doi: 10.1016/S0140-6736(20)30183-5

6. Lai C-C, Shih T-P, Ko W-C, Tang H-J, Hsueh P-R. Severe acute respiratory syndrome coronavirus 2 (SARS-CoV-2) and coronavirus disease-2019 (COVID-19): The epidemic and the challenges. Int J Antimicrob Agents (2020) 55:105924. doi: 10.1016/j.ijantimicag.2020.105924

7. Wu Y, Guo C, Tang L, Hong Z, Zhou J, Dong X, et al. Prolonged presence of SARS-CoV-2 viral RNA in faecal samples. Lancet Gastroenterol Hepatol (2020) 1253:20-1. doi: 10.1016/S2468-1253(20)30083-2

8. Yeo C, Kaushal S, Yeo D. Comment Enteric involvement of coronaviruses: is faecal - oral transmission of SARS-CoV-2 possible? Lancet Gastroenterol Hepatol (2020) 1253:2019-20. doi: 10.1016/S2468-1253(20)30048-0

9. Chan JFW, Yuan S, Kok KH, To KKW, Chu H, Yang J, et al. A familial cluster of pneumonia associated with the 2019 novel coronavirus indicating person-to-person transmission: a study of a family cluster. Lancet (2020) 395(10223):514-23. doi: 10.1016/S0140-6736(20)30154-9

10. Xu Y, Li X, Zhu B, Liang H, Fang C, Gong Y, et al. Characteristics of pediatric SARS-CoV-2 infection and potential evidence for persistent fecal viral shedding. Nat Med (2020) 26(4):502-5. doi: 10.1038/s41591020-0817-4

11. Rokni M, Ghasemi V, Tavakoli Z. Immune responses and pathogenesis of SARS-CoV-2 during an outbreak in Iran: Comparison with SARS and MERS. Rev Med Virol (2020) 30(3):e2107. doi: 10.1002/rmv.2107

12. Viego V, Geri M, Castiglia J, Jouglard E. Incubation period and serial interval of Covid-19 in a chain of infections in Bahia Blanca (Argentina). medRxiv (2020) 53(3):371-2. doi: 10.1101/2020.06.18.20134825

13. Lee PI, Hu YL, Chen PY, Huang YC, Hsueh PR. Are children less susceptible to COVID-19? J Microbiol Immunol Infect (2020) 53(3):371-2. doi: 10.1016/ j.jmii.2020.02.011

14. Bai Y, Yao L, Wei T, Tian F, Jin DY, Chen L, et al. Presumed Asymptomatic Carrier Transmission of COVID-19. JAMA J Am Med Assoc (2020) 323 (14):1406-7. doi: 10.1001/jama.2020.2565

15. Wu F, Zhao S, Yu B, Chen YM, Wang W, Song ZG, et al. A new coronavirus associated with human respiratory disease in China. Nature (2020) 579 (7798):265-9. doi: 10.1038/s41586-020-2008-3

16. Forni D, Cagliani R, Clerici M, Sironi M. Molecular Evolution of Human Coronavirus Genomes. Trends Microbiol (2017) 25(1):35-48. doi: 10.1016/ j.tim.2016.09.001

17. Fung S-Y, Yuen K-S, Ye Z-W, Chan C-P. Jin D-Y. A tug-of-war between severe acute respiratory syndrome coronavirus 2 and host antiviral defence: lessons from other pathogenic viruses. Emerg Microbes Infect (2020) 9:55870. doi: 10.1080/22221751.2020.1736644

18. Ahmed SF, Quadeer AA, McKay MR. Preliminary identification of potential vaccine targets for the COVID-19 Coronavirus (SARS-CoV-2) Based on SARS-CoV Immunological Studies. Viruses (2020) 12:1-15. doi: 10.3390/ v12030254

19. Wu A, Peng Y, Huang B, Ding X, Wang X, Niu P, et al. Genome Composition and Divergence of the Novel Coronavirus (2019-nCoV) Originating in China. Cell Host Microbe (2020) 27:325-8. doi: 10.1016/ j.chom.2020.02.001
20. Hoffmann M, Kleine-Weber H, Schroeder S, Krüger N, Herrler T, Erichsen S, et al. SARS-CoV-2 Cell Entry Depends on ACE2 and TMPRSS2 and Is Blocked by a Clinically Proven Protease Inhibitor. Cell (2020) 181(2):271-80. doi: 10.1016/j.cell.2020.02.052

21. Qi F, Qian S, Zhang S, Zhang Z. Single cell RNA sequencing of 13 human tissues identify cell types and receptors of human coronaviruses. Biochem Biophys Res Commun (2020) 526(1):135-40. doi: 10.1016/j.bbrc.2020.03.044

22. Zou X, Chen K, Zou J, Han P, Hao J, Han Z. Single-cell RNA-seq data analysis on the receptor ACE2 expression reveals the potential risk of different human organs vulnerable to $2019-\mathrm{nCoV}$ infection. Front Med (2020) 14(2):185-192. doi: 10.1007/s11684-020-0754-0

23. Nemunaitis J, Stanbery L, Senzer N. Severe acute respiratory syndrome coronavirus-2 (SARS-CoV-2) infection: let the virus be its own demise. Future Virol (2020). doi: 10.2217/fvl-2020-0068

24. Wölfel R, Corman VM, Guggemos W, Seilmaier M, Zange S, Müller MA, et al. Virological assessment of hospitalized patients with COVID-2019. Nature (2020) 581(7809):465-9. doi: 10.1038/s41586-020-2196-x

25. Hoffmann M, Kleine-Weber H, Pöhlmann S. A Multibasic Cleavage Site in the Spike Protein of SARS-CoV-2 Is Essential for Infection of Human Lung Cells. Mol Cell (2020) 78:779-84.e5. doi: 10.1016/j.molcel.2020.04.022

26. Jaimes JA, Millet JK, Whittaker GR. Proteolytic Cleavage of the SARS-CoV-2 Spike Protein and the Role of the Novel S1/S2 Site. iScience (2020) 23:101212. doi: 10.1016/j.isci.2020.101212

27. Xing Y, Li X, Gao X, Dong Q. Natural Polymorphisms Are Present in the Furin Cleavage Site of the SARS-CoV-2 Spike Glycoprotein. Front Genet (2020) 11:783. doi: 10.3389/fgene.2020.00783

28. Padmanabhan P, Desikan R, Dixit N. Targeting TMPRSS2 and Cathepsin B/ L Together May Be Synergistic Against SARS-CoV-2 Infection. ChemRxiv (2020) 1-41. doi: 10.26434/chemrxiv.12213125

29. Lauer SA, Grantz KH, Bi Q, Jones FK, Zheng Q, Meredith HR, et al. The Incubation Period of Coronavirus Disease 2019 (COVID-19) From Publicly Reported Confirmed Cases: Estimation and Application. Ann Intern Med (2020) M20-0504. doi: 10.7326/M20-0504

30. Yang X, Yu Y, Xu J, Shu H, Xia J, Liu H, et al. Clinical course and outcomes of critically ill patients with SARS-CoV-2 pneumonia in Wuhan, China: a single-centered, retrospective, observational study. Lancet Respir Med (2020) 2600:1-7. doi: 10.1016/S2213-2600(20)30079-5

31. Baig AM, Khaleeq A, Ali U, Syeda H. Evidence of the COVID-19 Virus Targeting the CNS: Tissue Distribution, Host-Virus Interaction, and Proposed Neurotropic Mechanisms. ACS Chem Neurosci (2020) 11(7):995-8. doi: 10.1021/acschemneuro.0c00122

32. Wang D, Hu B, Hu C, Zhu F, Liu X, Zhang J, et al. Clinical Characteristics of 138 Hospitalized Patients with 2019 Novel Coronavirus-Infected Pneumonia in Wuhan, China. JAMA J Am Med Assoc (2020) 323(11):1061-9. doi: $10.1001 /$ jama.2020.1585

33. Guan W, Ph D, Liang W, Zhao Y, Med M, Liang H, et al. Comorbidity and its impact on 1,590 patients with COVID-19 in China: A Nationwide Analysis. Eur Respir J (2020).

34. Hospital T. SARS-CoV-2: a potential novel etiology of fulminant myocarditis. Herz (2020) 10-2. doi: 10.1007/s00059-020-04909-z

35. Becker RC, Schweitzer A. Toward understanding the 2019 Coronavirus and its impact on the heart. J Thromb Thrombolysis (2020) 50(1):33-42. doi: $10.1007 /$ s11239-020-02107-6

36. Leung C. Clinical features of deaths in the novel coronavirus epidemic in China. Rev Med Virol (2020) e2103.1-4. doi: 10.1002/rmv.2103

37. WHO. Dir Open remarks media Brief COVID-19.

38. Baud D, Qi X, Nielsen-Saines K, Musso D, Pomar L, Favre G. Real estimates of mortality following COVID-19 infection. Lancet Infect Dis (2020) 20 (7):773. doi: 10.1016/S1473-3099(20)30195-X

39. Liu K, Chen Y, Lin R, Han K. young and middle-aged patients. J Infect (2020) 80(6):e14-8. doi: 10.1016/j.jinf.2020.03.005

40. Ye G, Pan Z, Pan Y, Deng Q, Chen L, Li J, et al. Clinical characteristics of severe acute respiratory syndrome coronavirus 2 reactivation. J Infect (2020) 80(5):e14-7. doi: 10.1016/j.jinf.2020.03.001

41. Zheng J, Zhou R, Chen F, Tang G, Wu K, Li F, et al. Incidence, clinical course and risk factor for recurrent pcr positivity in discharged covid-19 patients in guangzhou, china: A prospective cohort study. PloS Negl Trop Dis (2020) 14 (8):e0008648. doi: 10.1371/journal.pntd.0008648 
42. Coppola A, Annunziata A, Carannante N, Di Spirito V, Fiorentino G. Late Reactivation of SARS-CoV-2: A Case Report. Front Med (2020) 7:531. doi: 10.3389/fmed.2020.00531

43. Batisse D, Benech N, Botelho-Nevers E, Bouiller K, Collarino R, Conrad A, et al. Clinical recurrences of COVID-19 symptoms after recovery: viral relapse, reinfection or inflammatory rebound? J Infect (2020) 81(5):816-46. doi: 10.1016/j.jinf.2020.06.073

44. Fagre A, Lewis J, Eckley M, Zhan S, Rocha SM, Sexton NR, et al. SARS-CoV2 infection, neuropathogenesis and transmission among deer mice: Implications for reverse zoonosis to New World rodents. bioRxiv (2020). doi: 10.1101/2020.08.07.241810

45. Bohmwald K, Gálvez NMS, Ríos M, Kalergis AM. Neurologic Alterations Due to Respiratory Virus Infections. Front Cell Neurosci (2018) 12(386):115. doi: 10.3389/fncel.2018.00386

46. Espinoza JA, Bohmwald K, Cespedes PF, Gomez RS, Riquelme SA, Cortes $\mathrm{CM}$, et al. Impaired learning resulting from Respiratory Syncytial Virus infection. Proc Natl Acad Sci (2013) 110(22):9112-7. doi: 10.1073/ pnas. 1217508110

47. Ludlow M, Kortekaas J, Herden C, Hoffmann B, Tappe D, Trebst C, et al. Neurotropic virus infections as the cause of immediate and delayed neuropathology. Acta Neuropathol (2016) 131(2):159-84. doi: 10.1007/ s00401-015-1511-3

48. Fantetti KN, Gray EL, Ganesan P, Kulkarni A, O’Donnell LA. Interferon gamma protects neonatal neural stem/progenitor cells during measles virus infection of the brain. J Neuroinflammation (2016) 13(1):107. doi: 10.1186/ s12974-016-0571-1

49. Bohmwald K, Soto JA, Andrade C, Fernández-Fierro A, Espinoza JA, Ríos $\mathrm{M}$, et al. Lung pathology due to hRSV infection impairs blood-brain barrier permeability enabling astrocyte infection and a long-lasting inflammation in the CNS. Brain Behav Immun (2020). doi: 10.1016/j.bbi.2020.09.021

50. Netland J, Meyerholz DK, Moore S, Cassell M, Perlman S. Severe Acute Respiratory Syndrome Coronavirus Infection Causes Neuronal Death in the Absence of Encephalitis in Mice Transgenic for Human ACE2. J Virol (2008) 82(15):7264-75. doi: 10.1128/jvi.00737-08

51. Stodola JK, Dubois G, Le Coupanec A, Desforges M, Talbot PJ. The OC43 human coronavirus envelope protein is critical for infectious virus production and propagation in neuronal cells and is a determinant of neurovirulence and CNS pathology. Virology (2018) 515:134-49. doi: 10.1016/j.virol.2017.12.023

52. Dubé M, Le Coupanec A, Wong AHM, Rini JM, Desforges M, Talbot PJ. Axonal Transport Enables Neuron-to-Neuron Propagation of Human Coronavirus OC43. J Virol (2018) 92(17):e00404-18. doi: 10.1128/ jvi.00404-18

53. Desforges M, Le Coupanec A, Dubeau P, Bourgouin A, Lajoie L, Dubé M, et al. Human coronaviruses and other respiratory viruses: Underestimated opportunistic pathogens of the central nervous system? Viruses (2019) 12 (1):14. doi: 10.3390/v12010014

54. Stewart JN, Mounir S, Talbot PJ. Human coronavirus gene expression in the brains of multiple sclerosis patients. Virology (1992) 191(1):502-5. doi: 10.1016/0042-6822(92)90220-J

55. Cristallo A, Gambaro F, Biamonti G, Ferrante P, Battaglia M, Cereda PM. Human coronavirus polyadenylated RNA sequences in cerebrospinal fluid from multiple sclerosis patients. New Microbiol (1997) 20(2):105-14.

56. Chen R, Wang K, Yu J, Chen Z, Wen C, Xu Z. The spatial and cell-type distribution of SARS-CoV-2 receptor ACE2 in human and mouse brain. bioRxiv (2020). doi: 10.1101/2020.04.07.030650

57. Mao L, Wang M, Chen S, He Q, Chang J, Hong C, et al. Neurological Manifestations of Hospitalized Patients with COVID-19 in Wuhan, China: A Retrospective Case Series Study. SSRN Electron J (2020) 77(6):683-90. doi: 10.2139/ssrn.3544840

58. Moriguchi T, Harii N, Goto J, Harada D, Sugawara H, Takamino J, et al. A first Case of Meningitis/Encephalitis associated with SARS-Coronavirus-2. Int J Infect Dis (2020) 94:55-8. doi: 10.1016/j.ijid.2020.03.062

59. Zhao H, Shen D, Zhou H, Liu J, Chen S. Guillain-Barre syndrome associated with SARS-CoV-2 infection: causality or coincidence? Lancet Neurol (2020) 19(5):383-4. doi: 10.1016/S1474-4422(20)30109-5

60. Alquisiras-Burgos I, Peralta-Arrieta I, Alonso-Palomares LA, Zacapala-Gómez AE, Salmerón-Bárcenas EG, Aguilera P. Neurological Complications Associated with the Blood-Brain Barrier Damage Induced by the Inflammatory Response During SARS-CoV-2 Infection. Mol Neurobiol (2020) 1-16. doi: 10.1007/s12035-02002134-7

61. Giacomelli A, Pezzati L, Conti F, Bernacchia D, Siano M, Oreni L, et al. Selfreported olfactory and taste disorders in SARS-CoV-2 patients: a crosssectional study. Clin Infect Dis (2020) 71(15):889-90. doi: 10.1093/cid/ ciaa330

62. Wu Y, Xu X, Chen Z, Duan J, Hashimoto K, Yang L, et al. Nervous system involvement after infection with COVID-19 and other coronaviruses. Brain Behav Immun (2020) 874:18-22. doi: 10.1016/j.bbi.2020.03.031

63. Brann D, Tsukahara T, Weinreb C, Lipovsek M, Van den Berge K, Gong B, et al. Non-neural expression of SARS-CoV-2 entry genes in the olfactory epithelium suggests mechanisms underlying anosmia in COVID-19associated anosmia. Sci Adv (2020) 6(31):eabc5801. doi: 10.1126/sciadv. abc5801

64. Desforges M, Miletti TC, Gagnon M, Talbot PJ. Activation of human monocytes after infection by human coronavirus 229E. Virus Res (2007) 130(1-2):228-40. doi: 10.1016/j.virusres.2007.06.016

65. Buzhdygan TP, DeOre BJ, Baldwin-Leclair A, McGary H, Razmpour R, Galie $\mathrm{PA}$, et al. The SARSCoV2 spike protein alters barrier function in $2 \mathrm{D}$ static and 3D microfluidic in vitro models of the human blood-brain barrier. bioRxiv (2020). doi: 10.1101/2020.06.15.150912

66. Dando SJ, Mackay-Sim A, Norton R, Currie BJ, St. John JA, Ekberg JAK, et al. Pathogens penetrating the central nervous system: Infection pathways and the cellular and molecular mechanisms of invasion. Clin Microbiol Rev (2014) 27(4):691-726. doi: 10.1128/CMR.00118-13

67. Li Y-C, Bai W-Z, Hashikawa T. The neuroinvasive potential of SARS-CoV2 may play a role in the respiratory failure of COVID-19 patients. J Med virol (2020). doi: 10.1002/jmv.25728

68. Turtle L. Respiratory failure alone does not suggest central nervous system invasion by SARS-CoV-2. J Med Virol (2020) 92(7):705-6. doi: 10.1002/ jmv. 25828

69. Jensen S, Thomsen AR. Sensing of RNA Viruses: a Review of Innate Immune Receptors Involved in Recognizing RNA Virus Invasion. J Virol (2012) 86 (6):2900-10. doi: 10.1128/jvi.05738-11

70. Janeway CA, Medzhitov R. Innate immune recognition. Annu Rev Immunol (2002) 20:197-216. doi: 10.1146/annurev.immunol.20.083001.084359

71. Lee HC, Chathuranga K, Lee JS. Intracellular sensing of viral genomes and viral evasion. Exp Mol Med (2019) 51(12):1-13. doi: 10.1038/s12276-0190299-y

72. Okamoto M, Tsukamoto H, Kouwaki T, Seya T, Oshiumi H. Recognition of Viral RNA by Pattern Recognition Receptors in the Induction of Innate Immunity and Excessive Inflammation during Respiratory Viral Infections. Viral Immunol (2017) 30(6):408-20. doi: 10.1089/vim.2016.0178

73. Xagorari A, Chlichlia K. Toll-Like Receptors and Viruses: Induction of Innate Antiviral Immune Responses. Open Microbiol J (2008) 2:49-59. doi: 10.2174/1874285800802010049

74. Lund JM, Alexopoulou L, Sato A, Karow M, Adams NC, Gale NW, et al. Recognition of single-stranded RNA viruses by Toll-like receptor 7 . Proc Natl Acad Sci U S A (2004) 101(15):5598-603. doi: 10.1073/ pnas.0400937101

75. Astuti I,Y. Severe Acute Respiratory Syndrome Coronavirus 2 (SARS-CoV2): An overview of viral structure and host response. Diabetes Metab Syndr Clin Res Rev (2020) 14(4):407-12. doi: 10.1016/j.dsx.2020.04.020

76. Kurt-Jones EA, Popova L, Kwinn L, Haynes LM, Jones LP, Tripp RA, et al. Pattern recognition receptors TLR4 and CD14 mediate response to respiratory syncytial virus. Nat Immunol (2000) 1:398-401. doi: 10.1038/ 80833

77. Blanco-Melo D, Nilsson-Payant BE, Liu W-C, Uhl S, Hoagland D, Møller R, et al. Imbalanced host response to SARS-CoV-2 drives development of COVID-19. Cell (2020) 181:103645.e1e5. doi: 10.1016/ j.cell.2020.04.026

78. Hadjadj J, Yatim N, Barnabei L, Corneau A, Boussier J. Impaired type I interferon activity and inflammatory responses in severe COVID-19 patients. Science (2020) 724:718-24. doi: 10.1126/science.abc6027

79. Blanco-Melo D, Nilsson-Payant BE, Liu WC, Uhl S, Hoagland D, Møller R, et al. Imbalanced Host Response to SARS-CoV-2 Drives Development of COVID-19. Cell (2020) 181:1036-1045.e9. doi: 10.1016/j.cell.2020.04.026 
80. Li Q, Guan X, Wu P, Wang X, Zhou L, Tong Y, et al. Presumed Asymptomatic Carrier Transmission ofCOVID-19. N Engl J Med (2020) 323(14):1406-7. doi: 10.1056/nejmoa2001316

81. Chuan Q, Luoqi Z, Ziwei H, Zhang S. Dysregulation of immune response in patients with COVID-19 in Wuhan, China Chuan. J Chem Inf Model (2020) 71(15):762-8. doi: 10.1017/CBO9781107415324.004

82. Zhang B, Zhou X, Zhu C, Feng F, Qiu Y, Feng J, et al. Immune phenotyping based on neutrophil-to-lymphocyte ratio and IgG predicts disease severity and outcome for patients with COVID-19. medRxiv (2020), 2020.03.12.20035048. doi: 10.1101/2020.03.12.20035048

83. Qin C, Zhou L, Hu Z, Zhang S, Yang S, Tao Y, et al. Dysregulation of Immune Response in Patients With Coronavirus 2019 (COVID-19) in Wuhan, China. Clin Infect Dis (2020) 71(15):762-8. doi: 10.1093/cid/ ciaa 248

84. Fox SE, Akmatbekov A, Harbert JL, Li G, Quincy Brown J, Vander Heide RS. Pulmonary and cardiac pathology in African American patients with COVID-19: an autopsy series from New Orleans. Lancet Respir Med (2020) 8(7):681-6. doi: 10.1016/S2213-2600(20)30243-5

85. Zhang JJ, Dong X, Cao YY, Yuan Yd, Yang Yb, Yan Yq, et al. Clinical characteristics of 140 patients infected with SARS-CoV-2 in Wuhan, China. Allergy Eur J Allergy Clin Immunol (2020) 75(7):1730-41. doi: 10.1111/ all.14238

86. Chen J, Lau YF, Lamirande EW, Paddock CD, Bartlett JH, Zaki SR, et al. Cellular Immune Responses to Severe Acute Respiratory Syndrome Coronavirus (SARS-CoV) Infection in Senescent BALB/c Mice: CD4+ T Cells Are Important in Control of SARS-CoV Infection. J Virol (2010) 84:1289-301. doi: 10.1128/jvi.01281-09

87. Paolini R, Bernardini G, Molfetta R, Santoni A. NK cells and interferons. Cytokine Growth Factor Rev (2015) 26(2):113-20. doi: 10.1016/j.cytogfr. 2014.11.003

88. Shi Y, Tan M, Chen X, Liu Y, Huang J, Ou J, et al. Immunopathological characteristics of coronavirus disease 2019 cases in Guangzhou, China. medRxiv (2020) 2019:2020.03.12.20034736. doi: 10.1101/2020.03.12.20034736

89. Thevarajan I, Nguyen THO, Koutsakos M, Druce J, Caly L, van de Sandt CE, et al. Breadth of concomitant immune responses prior to patient recovery: a case report of non-severe COVID-19. Nat Med (2020) 1:1-3. doi: 10.1038/ s41591-020-0819-2

90. Mehta P, Mcauley DF, Brown M, Sanchez E, Tattersall RS, Manson JJ, et al. Correspondence COVID-19: consider cytokine storm syndromes and. Lancet (2020) 6736:19-20. doi: 10.1016/S0140-6736(20)30628-0

91. Wang J, Jiang M, Chen X, Montaner LJ. Cytokine storm and leukocyte changes in mild versus severe SARS-CoV-2 infection: Review of 3939 COVID-19 patients in China and emerging pathogenesis and therapy concepts. J Leukoc Biol (2020) 108(1):17-41. doi: 10.1002/ JLB.3COVR0520-272R

92. Xu Z, Shi L, Wang Y, Zhang J, Huang L, Zhang C, et al. Pathological findings of COVID-19 associated with acute respiratory distress syndrome. Lancet Respir Med (2020) 8:420-2. doi: 10.1016/S2213-2600(20)30076-X

93. Yang Y, Shen C, Li J, Yuan J, Yang M, Wang F, et al. Exuberant elevation of IP-10, MCP-3 and IL-1ra during SARS-CoV-2 infection is associated with disease severity and fatal outcome. medRxiv (2020). doi: 10.1101/ 2020.03.02.20029975

94. Mo P, Xing Y, Xiao Y, Deng L, Zhao Q, Wang H, et al. Clinical characteristics of refractory COVID-19 pneumonia in Wuhan, China. Clin Infect Dis (2020). doi: 10.1093/cid/ciaa270

95. Chen X, Zhao B, Qu Y, Chen Y, Xiong J, Feng Y, et al. Detectable serum SARS-CoV-2 viral load (RNAaemia) is closely associated with drastically elevated interleukin 6 (IL-6) level in critically ill COVID-19 patients. medRxiv (2020). doi: 10.1101/2020.02.29.20029520

96. Kahn R, Schmidt T, Golestani K, Mossberg A, Gullstrand B, Bengtsson AA, et al. Mismatch between circulating cytokines and spontaneous cytokine production by leukocytes in hyperinflammatory COVID-19. J Leukoc Biol (2020). doi: 10.1002/JLB.5COVBCR0720-310RR

97. Kox M, Waalders NJB, Kooistra EJ, Gerretsen J, Pickkers P. Cytokine Levels in Critically Ill Patients With COVID-19 and Other Conditions. Jama (2020) 324(15):1565-67. doi: 10.1001/jama.2020.17052

98. Herold T, Jurinovic V, Arnreich C, Hellmuth JC, Bergwelt-Baildon M, Klein M, et al. Level of IL-6 predicts respiratory failure in hospitalized symptomatic
COVID-19 patients. J Allergy Clin Immunol (2020) 146(1):128-36. doi: 10.1101/ 2020.04.01.20047381

99. Perlin DS, Zafir-Lavie I, Roadcap L, Raines S, Ware CF, Neil GA. Levels of the TNF-Related Cytokine LIGHT Increase in Hospitalized COVID-19 Patients with Cytokine Release Syndrome and ARDS. mSphere (2020) 5 (4):e00699-20. doi: 10.1128/msphere.00699-20

100. Yang Y, Shen C, Li J, Yuan J, Wei J, Huang F, et al. Plasma IP-10 and MCP-3 levels are highly associated with disease severity and predict the progression of COVID-19. J Allergy Clin Immunol (2020) 146(1):119-27.e4. doi: 10.1016/ j.jaci.2020.04.027

101. Morichi S, Kawashima H, Ioi H, Yamanaka G, Kashiwagi Y, Hoshika A, et al. Classification of acute encephalopathy in respiratory syncytial virus infection. J Infect Chemother (2011) 17(6):776-81. doi: 10.1007/s10156011-0259-5

102. Wang Z, Zhang A, Wan Y, Liu X, Qiu C, Xi X, et al. Early hypercytokinemia is associated with interferon-induced transmembrane protein-3 dysfunction and predictive of fatal H7N9 infection. Proc Natl Acad Sci U.S.A. (2014) 111 (2):769-74. doi: 10.1073/pnas.1321748111

103. Wong CK, Lam CWK, Wu AKL, Ip WK, Lee NLS, Chan IHS, et al. Plasma inflammatory cytokines and chemokines in severe acute respiratory syndrome. Clin Exp Immunol (2004) 136(1):95-103. doi: 10.1111/j.13652249.2004.02415.x

104. Mahallawi WH, Khabour OF, Zhang Q, Makhdoum HM, Suliman BA. MERS-CoV infection in humans is associated with a pro-inflammatory Th1 and Th17 cytokine profile. Cytokine (2018) 104:813. doi: 10.1016/ j.cyto.2018.01.025

105. Maleki KT, García M, Iglesias A, Alonso D, Ciancaglini M, Hammar U, et al. Serum markers associated with severity and outcome of hantavirus pulmonary syndrome. J Infect Dis (2019) 219(11):1832-40. doi: 10.1093/ infdis/jiz005

106. Khaiboullina SF, Levis S, Morzunov SP, Martynova EV, Anokhin VA, Gusev $\mathrm{OA}$, et al. Serum cytokine profiles differentiating hemorrhagic fever with renal syndrome and hantavirus pulmonary syndrome. Front Immunol (2017) 8:567. doi: 10.3389/fimmu.2017.00567

107. Kawamura Y, Miura H, Matsumoto Y, Uchida H, Kudo K, Hata T, et al. A case of Epstein-Barr virus-associated hemophagocytic lymphohistiocytosis with severe cardiac complications. BMC Pediatr (2016) 16(1):172. doi: 10.1186/s12887-016-0718-3

108. Crotty S. T Follicular Helper Cell Differentiation, Function, and Roles in Disease. Immunity (2014) 41(4):529-42. doi: 10.1016/j.immuni.2014.10.004

109. Varnaite R, García M, Glans H, Maleki KT, Sandberg JT, Tynell J, et al. Expansion of SARS-CoV-2-specific Antibody-secreting Cells and Generation of Neutralizing Antibodies in Hospitalized COVID-19 Patients. bioRxiv (2020). doi: 10.1101/2020.05.28.118729

110. Zhao J, Yuan Q, Wang H, Liu W, Liao X, Su Y, et al. Antibody Responses to SARS-CoV-2 in Patients of Novel Coronavirus Disease 2019. SSRN Electron J (2020) 71(16):2027-34. doi: 10.2139/ssrn.3546052

111. Chen Y, Tong X, Li Y, Gu B, Yan J, Liu Y, et al. A comprehensive, longitudinal analysis of humoral responses specific to four recombinant antigens of SARS-CoV-2 in severe and non-severe COVID-19 patients. PLoS Pathogens (2020) 16(9):1-16. doi: 10.1371/journal.ppat.1008796

112. Ciccullo A, Borghetti A, Zileri Dal Verme L, Tosoni A, Lombardi F, Garcovich M, et al. Neutrophil-to-lymphocyte ratio and clinical outcome in COVID-19: a report from the Italian front line. Int J Antimicrob Agents (2020) 56(2):106017. doi: 10.1016/j.ijantimicag.2020.106017

113. Yang AP, Liu JP, Tao WQ, Li HM. The diagnostic and predictive role of NLR, d-NLR and PLR in COVID-19 patients. Int Immunopharmacol (2020) 84:106504. doi: 10.1016/j.intimp.2020.106504

114. Liu J, Liu Y, Xiang P, Pu L, Xiong H, Li C, et al. Neutrophil-to-lymphocyte ratio predicts critical illness patients with 2019 coronavirus disease in the early stage. J Transl Med (2020) 18:206. doi: 10.1186/s12967-020-02374-0

115. Liu Y, Du X, Chen J, Jin Y, Peng L, Wang HHX, et al. Neutrophil-tolymphocyte ratio as an independent risk factor for mortality in hospitalized patients with COVID-19. J Infect (2020) 81(1):e6-12. doi: 10.1016/ j.jinf.2020.04.002

116. Zaim S, Chong JH, Sankaranarayanan V, Harky A. COVID-19 and Multiorgan Response. Curr Probl Cardiol (2020) 100618. doi: 10.1016/ j.cpcardiol.2020.100618 
117. Menter T, Haslbauer JD, Nienhold R, Savic S, Hopfer H, Deigendesch N, et al. Postmortem examination of COVID-19 patients reveals diffuse alveolar damage with severe capillary congestion and variegated findings in lungs and other organs suggesting vascular dysfunction. Histopathology (2020) 77 (2):198-209. doi: 10.1111/his.14134

118. Fernández-Rodríguez A, Casas I, Culebras E, Morilla E, Cohen MC, Alberola J. COVID-19 and post-mortem microbiological studies. Rev Esp Med Leg (2020) 46(3):127-38. doi: 10.1016/j.reml.2020.05.007

119. Carsana L, Sonzogni A, Nasr A, Rossi RS, Pellegrinelli A, Zerbi P, et al. Pulmonary post-mortem findings in a series of COVID-19 cases from northern Italy: a two-centre descriptive study. Lancet Infect Dis (2020) 20:1135-40. doi: 10.1016/S1473-3099(20)30434-5

120. Chu DK, Akl EA, Duda S, Solo K, Yaacoub S, Schünemann HJ, et al. Physical distancing, face masks, and eye protection to prevent person-to-person transmission of SARS-CoV-2 and COVID-19: a systematic review and meta-analysis. Lancet (2020) 395:1973-87. doi: 10.1016/S0140-6736(20) 31142-9

121. Xiong Y, Liu Y, Cao L, Wang D, Guo M, Jiang A, et al. Transcriptomic characteristics of bronchoalveolar lavage fluid and peripheral blood mononuclear cells in COVID-19 patients. Emerg Microbes Infect (2020) 9:761-70. doi: 10.1080/22221751.2020.1747363

122. Liu J, Li S, Liu J, Liang B, Wang X, Wang H, et al. Longitudinal characteristics of lymphocyte responses and cytokine profiles in the peripheral blood of SARS-CoV-2 infected patients. EBioMedicine (2020) 55:102763. doi: 10.1016/j.ebiom.2020.102763

123. Tecchio C, Micheletti A, Cassatella MA. Neutrophil-derived cytokines: Facts beyond expression. Front Immunol (2014) 5:508. doi: 10.3389/ fimmu.2014.00508

124. Allard B, Panariti A, Martin JG. Alveolar Macrophages in the Resolution of Inflammation, Tissue Repair, and Tolerance to Infection. Front Immunol (2018) 9:1777. doi: 10.3389/fimmu.2018.01777

125. Schaefer IM, Padera RF, Solomon IH, Kanjilal S, Hammer MM, Hornick JL, et al. In situ detection of SARS-CoV-2 in lungs and airways of patients with COVID-19. Mod Pathol (2020) 1-11. doi: 10.1038/s41379-0200595-z

126. Munster VJ, Feldmann F, Williamson BN, van Doremalen N, Pérez-Pérez L, Schulz J, et al. Respiratory disease in rhesus macaques inoculated with SARSCoV-2. Nature (2020) 585:268-72. doi: 10.1038/s41586-020-2324-7

127. Le TT, Cramer JP, Chen R, Mayhew S. Evolution of the COVID-19 vaccine development landscape. Nat Rev Drug Discovery (2020) 19(10):667-8. doi: 10.1038/d41573-020-00151-8

128. Krammer F. SARS-CoV-2 vaccines in development. Nature (2020) 586:51627. doi: 10.1038/s41586-020-2798-3

129. World Health Organization. Draft of the landscape of COVID-19 candidate vaccines. In: . World Heal Organ (2020). Available at: https://www.who.int/ blueprint/priority-diseases/key-action/novel-coronavirus-landscape-ncov. pdf?ua $=1$.

130. Department of Health and Human Services U. Clinical Trials. (2020).

131. Thompson KM, Gellin BG, Hinman AR, Orenstein WA. The National Vaccine Advisory Committee at 30: Impact and opportunity. Vaccine (2018) 36(11):1330-44. doi: 10.1016/j.vaccine.2018.01.068

132. Xia S, Duan K, Zhang Y, Zhao D, Zhang H, Xie Z, et al. Effect of an Inactivated Vaccine Against SARS-CoV-2 on Safety and Immunogenicity Outcomes: Interim Analysis of 2 Randomized Clinical Trials. Jama (2020) 324(10):951-60. doi: 10.1001/jama.2020.15543

133. Zhang Y, Zeng G, Pan H, Li C, Kan B, Hu Y, et al. Immunogenicity and Safety of a SARS-CoV-2 Inactivated Vaccine in Healthy Adults Aged 18-59 years: Report of the Randomized, Double-blind, and Placebo-controlled Phase 2 Clinical Trial. medrxiv (2020). doi: 10.1101/2020.07.31.20161216

134. Gao Q, Bao L, Mao H, Wang L, Xu K, Yang M, et al. Development of an inactivated vaccine candidate for SARS-CoV-2. Science (2020) 369(6499):7781. doi: $10.1126 /$ science.abc1932

135. Stage C, Report I, Vector V, Report I, Report S, Report S, et al. DRAFT landscape of COVID-19 candidate vaccines -. (2020).

136. Wang H, Zhang Y, Huang B, Deng W, Quan Y, Wang W, et al. Development of an Inactivated Vaccine Candidate, BBIBP-CorV, with Potent Protection against SARS-CoV-2. Cell (2020) 182:713-721.e9. doi: 10.1016/ j.cell.2020.06.008
137. Folegatti PM, Ewer KJ, Aley PK, Angus B, Becker S, Belij-Rammerstorfer S, et al. Safety and immunogenicity of the ChAdOx $1 \mathrm{nCoV}-19$ vaccine against SARS-CoV-2: a preliminary report of a phase $1 / 2$, single-blind, randomised controlled trial. Lancet (2020) 396(10249):467-78. doi: 10.1016/S0140-6736 (20)31604-4

138. WHO. WHO Coronavirus Disease (COVID 19) Dashboard (). (2020).

139. Zhu FC, Li YH, Guan XH, Hou LH, Wang WJ, Li JX, et al. Safety, tolerability, and immunogenicity of a recombinant adenovirus type- 5 vectored COVID19 vaccine: a dose-escalation, open-label, non-randomised, first-in-human trial. Lancet (2020) 395:1845-54. doi: 10.1016/S0140-6736(20)31208-3

140. Jackson LA, Anderson EJ, Rouphael NG, Roberts PC, Makhene M, Coler RN, et al. An mRNA Vaccine against SARS-CoV-2 - Preliminary Report. N Engl J Med (2020) 383(20):1920-31. doi: 10.1056/nejmoa2022483

141. Mulligan MJ, Lyke KE, Kitchin N, Absalon J, Gurtman A, Lockhart S, et al. Phase 1/2 study of COVID-19 RNA vaccine BNT162b1 in adults. Nature (2020) 586(7830):589-93. doi: 10.1038/s41586-020-2639-4

142. Sternberg A, Naujokat C. Structural features of coronavirus SARS-CoV-2 spike protein: Targets for vaccination. Life Sci (2020) 257:118056. doi: 10.1016/j.lfs.2020.118056

143. Tai W, He L, Zhang X, Pu J, Voronin D, Jiang S, et al. Characterization of the receptor-binding domain (RBD) of 2019 novel coronavirus: implication for development of RBD protein as a viral attachment inhibitor and vaccine. Cell Mol Immunol (2020) 17:613-20. doi: 10.1038/s41423-020-0400-4

144. Mandolesi M, Sheward DJ, Hanke L, Ma J, Pushparaj P, Vidakovics LP, et al. SARS-CoV-2 protein subunit vaccination elicits potent neutralizing antibody responses. BioRxiv (2020) 1-9. doi: 10.1101/2020.07.31.228486

145. Keech C, Albert G, Cho I, Robertson A, Reed P, Neal S, et al. Phase 1-2 Trial of a SARS-CoV-2 Recombinant Spike Protein Nanoparticle Vaccine. N Engl J Med (2020). doi: 10.1056/nejmoa2026920

146. Ura T, Okuda K, Shimada M. Developments in viral vector-based vaccines. Vaccines (2014) 2(3):624-41. doi: 10.3390/vaccines2030624

147. Robert-Guroff M. Replicating and non-replicating viral vectors for vaccine development. Curr Opin Biotechnol (2007) 18:546-56. doi: 10.1016/ j.copbio.2007.10.010

148. Bolinger B, Sims S, Swadling L, O’Hara G, de Lara C, Baban D, et al. Adenoviral Vector Vaccination Induces a Conserved Program of CD8+ T Cell Memory Differentiation in Mouse and Man. Cell Rep (2015) 13:157888. doi: 10.1016/j.celrep.2015.10.034

149. Tatsis N, Fitzgerald JC, Reyes-Sandoval A, Harris-McCoy KC, Hensley SE, Zhou $\mathrm{D}$, et al. Adenoviral vectors persist in vivo and maintain activated CD8+ T cells: Implications for their use as vaccines. Blood (2007) 110:1916-23. doi: 10.1182/blood-2007-02-062117

150. Case JB, Rothlauf PW, Chen RE, Kafai NM, Fox JM, Smith BK, et al. Replication-Competent Vesicular Stomatitis Virus Vaccine Vector Protects against SARS-CoV-2-Mediated Pathogenesis in Mice. Cell Host Microbe (2020) 28:465-74.e4. doi: 10.1016/j.chom.2020.07.018

151. Netea MG, Quintin J, Van Der Meer JWM. Trained immunity: A memory for innate host defense. Cell Host Microbe (2011) 9:355-61. doi: 10.1016/ j.chom.2011.04.006

152. Kleinnijenhuis J, Quintin J, Preijers F, Joosten LAB, Jacobs C, Xavier RJ, et al. BCG-induced trained immunity in NK cells: Role for non-specific protection to infection. Clin Immunol (2014) 155:213-9. doi: 10.1016/j.clim. 2014.10.005

153. Kleinnijenhuis J, Quintin J, Preijers F, Joosten LAB, Ifrim DC, Saeed S, et al. Bacille Calmette-Guérin induces NOD2-dependent nonspecific protection from reinfection via epigenetic reprogramming of monocytes. Proc Natl Acad Sci U S A (2012) 109:17537-42. doi: 10.1073/pnas.1202870109

154. Kleinnijenhuis J, Van Crevel R, Netea MG. Trained immunity: Consequences for the heterologous effects of BCG vaccination. Trans $R$ Soc Trop Med Hyg (2014) 109:29-35. doi: 10.1093/trstmh/tru168

155. Arts RJW, Blok BA, Aaby P, Joosten LAB, de Jong D, van der Meer JWM, et al. Long-term in vitro and in vivo effects of $\gamma$-irradiated BCG on innate and adaptive immunity. J Leukoc Biol (2015) 98:995-1001. doi: 10.1189/ jlb.4ma0215-059r

156. Arts RJW, Moorlag SJCFM, Novakovic B, Li Y, Wang SY, Oosting M, et al. BCG Vaccination Protects against Experimental Viral Infection in Humans through the Induction of Cytokines Associated with Trained Immunity. Cell Host Microbe (2018) 23:89-100. doi: 10.1016/j.chom.2017.12.010 
157. Covián C, Fernández-Fierro A, Retamal-Díaz A, Díaz FE, Vasquez AE, Lay MK, et al. BCG-Induced Cross-Protection and Development of Trained Immunity: Implication for Vaccine Design. Front Immunol (2019) 10:2806. doi: 10.3389/fimmu.2019.02806

158. Covián C, Retamal-Diaz A, Bueno SM, Kalergis AM. Could BCG vaccination induce protective trained immunity for SARS-CoV-2? Front Immunol (2020) 11:970. doi: 10.3389/FIMMU.2020.00970

159. Mohamed Hussein AAR, Salem MR, Salman S, Abdulrahim AF, Al Massry NA, Saad M, et al. Correlation between COVID-19 case fatality rate and percentage of BCG vaccination: is it true the vaccine is protective? Egypt $J$ Bronchol (2020) 14(1):25. doi: 10.1186/s43168-020-00022-1

160. O'Neill LAJ, Netea MG. BCG-induced trained immunity: can it offer protection against COVID-19? Nat Rev Immunol (2020) 20(6):335-6. doi: 10.1038/s41577-020-0337-y

161. Jirjees FJ, Dallal Bashi YH, Al-Obaidi HJ. COVID-19 death and BCG vaccination programs worldwide. Tuberc Respir Dis (2020). doi: 10.4046/ trd.2020.0063

162. Amirlak I, Haddad R, Hardy JD, Khaled NS, Chung MH, Amirlak B. Effectiveness of booster BCG vaccination in preventing Covid-19 infection. medRxiv (2020). doi: 10.1101/2020.08.10.20172288

163. National Institutes of Health. ClinicalTrials.gov: Bacillus Calmette Guerin and COVID. NIH (2020).

164. World Health Organization. Bacille Calmette-Guerin (BCG) vaccination and COVID-19. WHO (2020).

165. Ali MJ, Hanif M, Haider MA, Ahmed MU, Sundas F, Hirani A, et al. Treatment Options for COVID-19: A Review. Front Med (2020) 7:480:480. doi: $10.3389 /$ fmed.2020.00480

166. Beigel JH, Tomashek KM, Dodd LE, Mehta AK, Zingman BS, Kalil AC, et al. Remdesivir for the Treatment of Covid-19 - Preliminary Report. N Engl J Med (2020) 383(19):1813-26. doi: 10.1056/NEJMoa2007764

167. Hemmati F, Saedi S, Hemmati-Dinarvand M, Zarei M, Seghatoleslam A. Mysterious Virus: A Review on Behavior and Treatment Approaches of the Novel Coronavirus, 2019-nCoV. Arch Med Res (2020) 51:375-83. doi: 10.1016/j.arcmed.2020.04.022

168. Wang M, Cao R, Zhang L, Yang X, Liu J, Xu M, et al. Remdesivir and chloroquine effectively inhibit the recently emerged novel coronavirus (2019nCoV) in vitro. Cell Res (2020) 30(3):269-71. doi: 10.1038/s41422-020-0282-0

169. Holshue ML, DeBolt C, Lindquist S, Lofy KH, Wiesman J, Bruce H, et al. First case of 2019 novel coronavirus in the United States. N Engl J Med (2020) 382(10):929-36. doi: 10.1056/NEJMoa2001191

170. Du Y-X, Chen X-P. Favipiravir: pharmacokinetics and concerns about clinical trials for 2019-nCoV infection. Clin Pharmacol Ther (2020) 108 (2):242-7. doi: 10.1002/cpt.1844

171. Cai Q, Yang M, Liu D, Chen J, Shu D, Xia J, et al. Experimental Treatment with Favipiravir for COVID-19: An Open-Label Control Study. Eng (Beijing China) (2020). doi: 10.1016/j.eng.2020.03.007

172. Kim JY. Letter to the editor: Case of the index patient who caused tertiary transmission of coronavirus disease 2019 in Korea: The application of lopinavir/ritonavir for the treatment of COVID-19 pneumonia monitored by quantitative RT-PCR. J Korean Med Sci (2020) 35:1-6. doi: 10.3346/ jkms.2020.35.e88

173. Walls AC, Park YJ, Tortorici MA, Wall A, McGuire AT, Veesler D. Structure, Function, and Antigenicity of the SARS-CoV-2 Spike Glycoprotein. Cell (2020) 181(2):281-92.e6. doi: 10.1016/j.cell.2020.02.058

174. Cheng CY, Lee YL, Chen CP, Lin YC, Liu CE, Liao CH, et al. Lopinavir/ ritonavir did not shorten the duration of SARS CoV-2 shedding in patients with mild pneumonia in Taiwan. J Microbiol Immunol Infect (2020) 53:48892. doi: $10.1016 /$ j.jmii.2020.03.032

175. Bhatnagar T, Murhekar MV, Soneja M, Gupta N, Giri S, Wig N, et al. Lopinavir/ritonavir combination therapy amongst symptomatic coronavirus disease 2019 patients in India: Protocol for restricted public health emergency use. Indian J Med Res (2020) 151:184-9. doi: 10.4103/ ijmr.IJMR_502_20

176. Wang X, Cao R, Zhang H, Liu J, Xu M, Hu H, et al. The anti-influenza virus drug, arbidol is an efficient inhibitor of SARS-CoV-2 in vitro. Cell Discovery (2020) 6:4-8. doi: 10.1038/s41421-020-0169-8

177. Kumar M, Topno RK, Dikhit MR, Bhawana, GC S, Madhukar M, et al. Molecular docking studies of chloroquine and its derivatives against P23pro- zbd domain of chikungunya virus: Implication in designing of novel therapeutic strategies. J Cell Biochem (2019) 120(10):18298-308. doi: $10.1002 /$ jcb. 29139

178. Funck-Brentano C, Salem J-E. Chloroquine or hydroxychloroquine for COVID-19: why might they be hazardous? Lancet (London England) (2020) S0140-6736(20)31174-0. doi: 10.1016/S0140-6736(20)31174-0

179. Wong YK, Yang J, He Y. Caution and clarity required in the use of chloroquine for COVID-19. Lancet Rheumatol (2020) 2:e255. doi: 10.1016/ S2665-9913(20)30093-X

180. Funck-Brentano C, Nguyen LS, Salem J-E. Retraction and republication: cardiac toxicity of hydroxychloroquine in COVID-19. Lancet (London England) (2020) 396(10245):e2-3. doi: 10.1016/S0140-6736(20)31528-2

181. Nguyen LS, Dolladille C, Drici MD, Fenioux C, Alexandre J, Mira JP, et al. Cardiovascular Toxicities Associated With Hydroxychloroquine and Azithromycin: An Analysis of the World Health Organization Pharmacovigilance Database. Circulation (2020) 142:303-5. doi: 10.1161/ CIRCULATIONAHA.120.048238

182. Zhang R, Wang X, Ni L, Di X, Ma B, Niu S, et al. COVID-19: Melatonin as a potential adjuvant treatment. Life Sci (2020) 250:117583. doi: 10.1016/ j.lfs. 2020.117583

183. Zhou Y, Hou Y, Shen J, Huang Y, Martin W, Cheng F. Network-based drug repurposing for novel coronavirus 2019-nCoV/SARS-CoV-2. Cell Discovery (2020) 6:30417-5. doi: 10.1038/s41421-020-0153-3

184. Villar J, Ferrando C, Martínez D, Ambrós A, Muñoz T, Soler JA, et al. Dexamethasone treatment for the acute respiratory distress syndrome: a multicentre, randomised controlled trial. Lancet Respir Med (2020) 8:267-76. doi: 10.1016/\$2213-2600(19)30417-5

185. Shen C. Treatment of 5 Critically Ill Patients With COVID-19 With Convalescent Plasma. JAMA (2020) 323(16):1-8. doi: 10.1001/jama.2020.4783

186. Duan K, Liu B, Li C, Zhang H, Yu T, Qu J, et al. Effectiveness of convalescent plasma therapy in severe COVID-19 patients. Proc Natl Acad Sci U.S.A. (2020) 117(17):94909496. doi: 10.1073/pnas.2004168117

187. Garrido JL, Prescott J, Calvo M, Bravo F, Alvarez R, Salas A, et al. Two recombinant human monoclonal antibodies that protect against lethal Andes hantavirus infection in vivo. Sci Transl Med (2018) 10(468):eaat6420. doi: $10.1126 /$ scitranslmed.aat 6420

188. Mire CE, Cross RW, Geisbert JB, Borisevich V, Agans KN, Deer DJ, et al. Human-monoclonal-antibody therapy protects nonhuman primates against advanced Lassa fever. Nat Med (2017) 23(10):1146-9. doi: 10.1038/ nm.4396

189. Rijal P, Elias SC, Machado SR, Xiao J, Schimanski L, O’Dowd V, et al. Therapeutic Monoclonal Antibodies for Ebola Virus Infection Derived from Vaccinated Humans. Cell Rep (2019) 27(1):172-86.e7. doi: 10.1016/ j.celrep.2019.03.020

190. Mire CE, Geisbert JB, Borisevich V, Fenton KA, Agans KN, Flyak AI, et al. Therapeutic treatment of marburg and ravn virus infection in nonhuman primates with a human monoclonal antibody. Sci Transl Med (2017) 9(384): eaai8711. doi: 10.1126/scitranslmed.aai8711

191. Takashita E. Influenza Polymerase Inhibitors: Mechanisms of Action and Resistance. Cold Spring Harb Perspect Med (2020) a038687. doi: 10.1101/ cshperspect.a038687

192. Monteil V, Kwon H, Prado P, Hagelkrüys A, Wimmer RA. Inhibition of SARS-CoV-2 infections in engineered human tissues using clinical-grade soluble human ACE2. Cell (2020) 181:90513. doi: 10.1016/j.cell.2020.04.004

193. Cao X. COVID-19: immunopathology and its implications for therapy. Nat Rev Immunol (2020) 2019:269-70. doi: 10.1038/s41577-020-0308-3

194. Gordon CJ, Tchesnokov EP, Feng JY, Porter DP, Gotte M. The antiviral compound remdesivir potently inhibits RNA-dependent RNA polymerase from Middle East respiratory syndrome coronavirus. J Biol Chem (2020) 295 (15):4773-9. doi: 10.1074/jbc.AC120.013056

195. Hinton DM. Food and Drug Administration. Remdesivir EUA Letter of Authorization (). (2020).

196. Cvetkovic RS, Goa KL. Lopinavir/ritonavir: A review of its use in the management of HIV infection. Drugs (2003) 63(8):769-802. doi: 10.2165/ 00003495-200363080-00004

197. Cao B, Wang Y, Wen D, Liu W, Wang J, Fan G, et al. A Trial of LopinavirRitonavir in Adults Hospitalized with Severe Covid-19. N Engl J Med (2020) 382(19):1787-99. doi: 10.1056/NEJMoa2001282 
198. Hung IFN, Lung KC, Tso EYK, Liu R, Chung TWH, Chu MY, et al. Triple combination of interferon beta-1b, lopinavir-ritonavir, and ribavirin in the treatment of patients admitted to hospital with COVID-19: an open-label, randomised, phase 2 trial. Lancet (2020) 395(10238):1695-704. doi: 10.1016/ S0140-6736(20)31042-4

199. Blaising J, Polyak SJ, Pécheur E. Arbidol as a broad-spectrum antiviral: An update. Europe PMC (2020).

200. Zhu Z, Lu Z, Xu T, Chen C, Yang G, Zha T. Arbidol monotherapy is superior to lopinavir / ritonavir in treating (). (2020) 19-22. doi: 10.1016/j.jinf.2020. 03.060

201. Deng L, Li C, Zeng Q, Liu X, Li X, Zhang H, et al. Arbidol combined with LPV / $\mathrm{r}$ versus LPV / $\mathrm{r}$ alone against Corona Virus Disease 2019: A retrospective cohort study. J Infect (2020) 81:e1-5. doi: 10.1016/j.jinf. 2020.03.002

202. Wang Z, Yang B, Li Q, Wen L, Zhang R. Clinical Features of 69 Cases With Coronavirus Disease 2019 in Wuhan, China. Clin Infect Dis Off Publ Infect Dis Soc Am (2020) 71:769-77. doi: 10.1093/cid/ciaa272

203. Schijns V, Lavelle EC. Prevention and treatment of COVID-19 disease by controlled modulation of innate immunity. Eur J Immunol (2020) 50:932-8. doi: $10.1002 /$ eji.202048693

204. Davis LS, Reimold AM. Research and therapeutics-traditional and emerging therapies in systemic lupus erythematosus. In: Rheumatol (United Kingdom) Rheumatology Oxford (2017). doi: 10.1093/rheumatology/kew417

205. Al-Bari AA. Chloroquine analogues in drug discovery: New directions of uses, mechanisms of actions and toxic manifestations from malaria to multifarious diseases. J Antimicrob Chemother (2014) 70(6):1608-21. doi: $10.1093 / \mathrm{jac} / \mathrm{dkv} 018$

206. Vincent MJ, Bergeron E, Benjannet S, Erickson BR, Rollin PE, Ksiazek TG, et al. Chloroquine is a potent inhibitor of SARS coronavirus infection and spread. Virol J (2005) 2:69. doi: 10.1186/1743-422X-2-69

207. Li X, Wang Y, Agostinis P, Rabson A, Melino G, Carafoli E, et al. Is hydroxychloroquine beneficial for COVID-19 patients? Cell Death Dis (2020) 11:1-6. doi: 10.1038/s41419-020-2721-8

208. Singh AK, Singh A, Shaikh A, Singh R, Misra A. Chloroquine and hydroxychloroquine in the treatment of COVID-19 with or without diabetes: A systematic search and a narrative review with a special reference to India and other developing countries. Diabetes Metab Syndr Clin Res Rev (2020) 14(3):241-6. doi: 10.1016/j.dsx.2020.03.011

209. Tiwari V, Beer JC, Sankaranarayanan NV, Swanson-Mungerson M, Desai UR. Discovering small-molecule therapeutics against SARS-CoV-2. Drug Discovery Today (2020) 25(8):1535-44. doi: 10.1016/j.drudis.2020. 06.017

210. Galano A, Castañeda-Arriaga R, Pérez-González A, Tan DX, Reiter RJ. Phenolic melatonin-related compounds: Their role as chemical protectors against oxidative stress. Molecules (2016) 21(11):1442. doi: 10.3390/ molecules 21111442

211. Lotufo CMC, Yamashita CE, Farsky SHP, Markus RP. Melatonin effect on endothelial cells reduces vascular permeability increase induced by leukotriene B4. Eur J Pharmacol (2006) 534(1-3):258-63. doi: 10.1016/ j.ejphar.2006.01.050

212. Tan DX, Korkmaz A, Reiter RJ, Manchester LC. Ebola virus disease: Potential use of melatonin as a treatment. J Pineal Res (2014) 57(4):381-4. doi: $10.1111 /$ jpi.12186

213. Báez-Santos YM, St. John SE, Mesecar AD. The SARS-coronavirus papainlike protease: Structure, function and inhibition by designed antiviral compounds. Antiviral Res (2015 115:21-38. doi: 10.1016/j.antiviral. 2014.12.015

214. Lambert DW, Clarke NE, Hooper NM, Turner AJ. Calmodulin interacts with angiotensin-converting enzyme-2 (ACE2) and inhibits shedding of its ectodomain. FEBS Lett (2008) 582(2):385-90. doi: 10.1016/j.febslet. 2007.11.085

215. Horby P, Lim WS, Emberson JR, Mafham M, Bell JL, Linsell L, et al. Dexamethasone in hospitalized patients with Covid-19-preliminary report. N Engl J Med (2020) NEJMoa2021436. doi: 10.1056/NEJMoa2021436

216. Li H, Yang SG, Gu L, Zhang Y, Yan XX, Liang ZA, et al. Effect of low-tomoderate-dose corticosteroids on mortality of hospitalized adolescents and adults with influenza $\mathrm{A}(\mathrm{H} 1 \mathrm{~N} 1) \mathrm{pdm} 09$ viral pneumonia. Influenza Other Respi Viruses (2017) 11(4):345-54. doi: 10.1111/irv.12456
217. Chen RC, Tang XP, Tan SY, Liang BL, Wan ZY, Fang JQ, et al. Treatment of severe acute respiratory syndrome with glucosteroids: The Guangzhou experience. Chest (2006) 129(6):1441-52. doi: 10.1378/chest.129.6.1441

218. Psaltopoulou T, Sergentanis T, Pappa V, Politou M, Terpos E, Tsiodras S, et al. The Emerging Role of Convalescent Plasma in the Treatment of COVID-19. HemaSphere (2020) 4:e409. doi: 10.1097/HS9. 0000000000000409

219. Maor Y, Cohen D, Paran N, Israely T, Ezra V, Axelrod O, et al. Compassionate use of convalescent plasma for treatment of moderate and severe pneumonia in COVID-19 patients and association with IgG antibody levels in donated plasma. EClinicalMedicine (2020) 100525. doi: 10.1016/ j.eclinm. 2020.100525

220. Hung IFN, To KKW, Lee CK, Lee KL, Chan K, Yan WW, et al. Convalescent plasma treatment reduced mortality in patients with severe pandemic influenza A (H1N1) 2009 virus infection. Clin Infect Dis (2011) 52(4):44756. doi: $10.1093 / \mathrm{cid} / \mathrm{ciq} 106$

221. Zhou B, Zhong N, Guan Y. Treatment with convalescent plasma for influenza A (H5N1) infection. N Engl J Med (2007) 357(14):1450-1. doi: 10.1056/NEJMc070359

222. Van Griensven J, Edwards T, De Lamballerie X, Semple MG, Gallian P, Baize S, et al. Evaluation of convalescent plasma for Ebola virus disease in Guinea. N Engl J Med (2016) 374(1):33-42. doi: 10.1056/NEJMoa1511812

223. Agnihothram S, Gopal R, Yount BL, Donaldson EF, Menachery VD, Graham RL, et al. Evaluation of serologic and antigenic relationships between middle eastern respiratory syndrome coronavirus and other coronaviruses to develop vaccine platforms for the rapid response to emerging coronaviruses. J Infect Dis (2014) 209(7):995-1006. doi: 10.1093/infdis/jit609

224. Cheng Y, Wong R, Soo YOY, Wong WS, Lee CK, Ng MHL, et al. Use of convalescent plasma therapy in SARS patients in Hong Kong. Eur J Clin Microbiol Infect Dis (2005) 24(1):44-6. doi: 10.1007/s10096-004-1271-9

225. Rojas M, Rodríguez Y, Monsalve DM, Acosta-ampudia Y, Camacho B, Esteban J, et al. Convalescent plasma in Covid-19: Possible mechanisms of action (). (2020). doi: 10.1016/j.autrev.2020.102554

226. Vial PA, Valdivieso F, Calvo M, Rioseco ML, Riquelme R, Araneda A, et al. A non-randomized multicentre trial of human immune plasma for treatment of hantavirus cardiopulmonary syndrome caused by Andes virus. Antivir Ther (2015) 20:377-86. doi: 10.3851/IMP2875

227. Vyas SP, GN. Adverse effects of plasma transfusion. Transfusion (2013) 52:1-23. doi: 10.1111/j.1537-2995.2012.03663.x.Adverse

228. Toy P, Lowell C. TRALI - Definition, mechanisms, incidence and clinical relevance. Best Pract Res Clin Anaesthesiol (2007) 21:183-93. doi: 10.1016/ j.bpa.2007.01.003

229. Toy P. Update on transfusion-related acute lung injury. Clin Adv Hematol Oncol (2019) 17:378-81.

230. Zhao Q, He Y. Challenges of Convalescent Plasma Therapy on COVID-19. J Clin Virol (2020) 127:104358. doi: 10.1016/j.jcv.2020.104358

231. Li L, Li L, Zhang W, Zhang W, Hu Y, Tong X, et al. Effect of Convalescent Plasma Therapy on Time to Clinical Improvement in Patients with Severe and Life-threatening COVID-19: A Randomized Clinical Trial. JAMA J Am Med Assoc (2020) 324(5):1-11. doi: 10.1001/jama.2020.10044

232. Kadlec RP. Convalescent Plasma COVID-19 Letter of Authorization (). (2020) 564:1-7.

233. Administration F and D. Recommendations for Investigational COVID-19 Convalescent Plasma. Available at: https://www.fda.gov/vaccines-bloodbiologics/inves.

234. Jin Y, Lei C, Hu D, Dimitrov DS, Ying T. Human monoclonal antibodies as candidate therapeutics against emerging viruses. Front Med (2017) 11 (4):462-70. doi: 10.1007/s11684-017-0596-6

235. Ejemel M, Li Q, Hou S, Schiller ZA, Tree JA, Wallace A, et al. A crossreactive human IgA monoclonal antibody blocks SARS-CoV-2 spikeACE2 interaction. Nat Commun (2020) 11:4198. doi: 10.1038/s41467-02018058-8

236. Ying T, Du L, Ju TW, Prabakaran P, Lau CCY, Lu L, et al. Exceptionally Potent Neutralization of Middle East Respiratory Syndrome Coronavirus by Human Monoclonal Antibodies. J Virol (2014) 88(14):7796-805. doi: 10.1128/jvi.00912-14

237. Ter Meulen J, Bakker ABH, Van Den Brink EN, Weverling GJ, Martina BEE, Haagmans BL, et al. Human monoclonal antibody as prophylaxis for SARS 
coronavirus infection in ferrets. Lancet (2004) 363(9427):2139-41. doi: 10.1016/S01406736(04)16506-9

238. Morrey JD, Siddharthan V, Olsen AL, Roper GY, Wang H, Baldwin TJ, et al. Humanized monoclonal antibody against West Nile virus envelope protein administered after neuronal infection protects against lethal encephalitis in hamsters. J Infect Dis (2006) 194(9):1300-8. doi: 10.1086/508293

239. Ju B, Zhang Q, Ge J, Wang R, Sun J, Ge X, et al. Human neutralizing antibodies elicited by SARS-CoV-2 infection. Nature (2020) 584(7819):1159. doi: $10.1038 / \mathrm{s} 41586-020-2380-\mathrm{z}$

240. Liu L, Wang P, Nair MS, Yu J, Rapp M, Wang Q, et al. Potent neutralizing antibodies directed to multiple epitopes on SARS-CoV-2 spike. Nature (2020) 450:456. doi: 10.1038/s41586-020-2571-7

241. Shi R, Shan C, Duan X, Chen Z, Liu P, Song J, et al. A human neutralizing antibody targets the receptor-binding site of SARS-CoV-2. Nature (2020) 584:120-4. doi: 10.1038/s41586-020-2381-y

242. Regeneron. Developing REGN-COV2. Available at: https://www.regeneron. com/covid19.

243. Baum A, Fulton BO, Wloga E, Copin R, Pascal KE, Russo V, et al. Antibody cocktail to SARS-CoV-2 spike protein prevents rapid mutational escape seen with individual antibodies. Sci (80- ) (2020) eabd0831. doi: 10.1126/ science.abd0831

244. Morena V, Milazzo L, Oreni L, Bestetti G, Fossali T, Bassoli C, et al. Offlabel use of tocilizumab for the treatment of SARS-CoV-2 pneumonia in Milan, Italy. Eur J Intern Med (2020) 76:36-42. doi: 10.1016/j.ejim. 2020.05.011

245. National Institutes of Health. ClinicalTrials.gov-monoclonal antibodies against COVID-19. NIH (2020). Available at: https:/clinicaltrials.gov/ct2/ results? cond=monocl.

246. National Institutes of Health. Clinical trials of monoclonal antibodies to prevent COVID-19 now enrolling.

247. Hanke L, Perez LV, Sheward D, Das H, Schulte T, Moliner-Morro A, et al. An alpaca nanobody neutralizes SARS-CoV-2 by blocking receptor interaction. Nat Commun (2020) 11:4420. doi: 10.1101/2020.06.02. 130161

248. Jovčevska I, Muyldermans S. The Therapeutic Potential of Nanobodies. BioDrugs (2020) 34(1):11-26. doi: 10.1007/s40259-019-00392-z

249. Huo J, Le Bas A, Ruza RR, Duyvesteyn HME, Mikolajek H, Malinauskas T, et al. Neutralizing nanobodies bind SARS-CoV-2 spike RBD and block interaction with ACE2. Nat Struct Mol Biol 2020) (9):846-54. doi: 10.1038/ s41594-020-0469-6
250. Kindler E, Thiel V, Weber F. Interaction of SARS and MERS Coronaviruses with the Antiviral Interferon Response. Adv Virus Res (2016) 96:219-43. doi: 10.1016/bs.aivir.2016.08.006

251. Channappanavar R, Fett C, Zhao J, Meyerholz DK, Perlman S. Virus-Specific Memory CD8 T Cells Provide Substantial Protection from Lethal Severe Acute Respiratory Syndrome Coronavirus Infection. J Virol (2014) (19):11034-44. doi: 10.1128/jvi.01505-14

252. Tang F, Quan Y, Xin Z-T, Wrammert J, Ma M-J, Lv H, et al. Lack of Peripheral Memory B Cell Responses in Recovered Patients with Severe Acute Respiratory Syndrome: A Six-Year Follow-Up Study. J Immunol (2011) 186(12):7264-8. doi: 10.4049/jimmunol.0903490

253. Zhao J, Zhao J, Mangalam AK, Channappanavar R, Fett C, Meyerholz DK, et al. Airway Memory CD4+ T Cells Mediate Protective Immunity against Emerging Respiratory Coronaviruses. Immunity (2016) 44(6):1379-91. doi: 10.1016/j.immuni.2016.05.006

254. Lu Y, Sun K, Guo S, Wang J, Li A, Rong X, et al. Early Warning Indicators of Severe COVID-19: A Single-Center Study of Cases From Shanghai, China. Front Med (2020) 7:432. doi: 10.3389/fmed.2020.00432

255. Copaescu A, Smibert O, Gibson A, Phillips EJ, Trubiano JA. The role of IL-6 and other mediators in the cytokine storm associated with SARS-CoV-2 infection. J Allergy Clin Immunol (2020) 146:518-34.e1. doi: 10.1016/j.jaci.2020.07.001

256. NIH. Coronavirus Disease 2019 (COVID-19) Treatment Guidelines. Disponible en, NIH Vol. 2019. (2020). p. 130. Available at: https:// covid19treatmentguidelines.nih.gov/.

257. Oestereich L, Lüdtke A, Wurr S, Rieger T, Muñoz-Fontela C, Günther S. Successful treatment of advanced Ebola virus infection with T-705 (favipiravir) in a small animal model. Antivir Res (2014) 105:17-21. doi: 10.1016/j.antiviral.2014.02.014

Conflict of Interest: The authors declare that the research was conducted in the absence of any commercial or financial relationships that could be construed as a potential conflict of interest.

Copyright (๑) 2020 Canedo-Marroquin, Saavedra, Andrade, Berrios, Rodríguez-Guilarte, Opazo, Riedel and Kalergis. This is an open-access article distributed under the terms of the Creative Commons Attribution License (CC BY). The use, distribution or reproduction in other forums is permitted, provided the original author(s) and the copyright owner(s) are credited and that the original publication in this journal is cited, in accordance with accepted academic practice. No use, distribution or reproduction is permitted which does not comply with these terms. 